\title{
Why do firms issue convertible bonds? Evidence from the field
}

DOI:

10.2139/ssrn. 1908476

\section{Document Version}

Accepted author manuscript

Link to publication record in Manchester Research Explorer

\section{Citation for published version (APA):}

Dong, M., Dutordoir, M., \& Veld, C. (2017). Why do firms issue convertible bonds? Evidence from the field. Critical Finance Review, 7(1), 111-164. https://doi.org/10.2139/ssrn.1908476

\section{Published in:}

Critical Finance Review

\section{Citing this paper}

Please note that where the full-text provided on Manchester Research Explorer is the Author Accepted Manuscript or Proof version this may differ from the final Published version. If citing, it is advised that you check and use the publisher's definitive version.

\section{General rights}

Copyright and moral rights for the publications made accessible in the Research Explorer are retained by the authors and/or other copyright owners and it is a condition of accessing publications that users recognise and abide by the legal requirements associated with these rights.

\section{Takedown policy}

If you believe that this document breaches copyright please refer to the University of Manchester's Takedown Procedures [http://man.ac.uk/04Y6Bo] or contact uml.scholarlycommunications@manchester.ac.uk providing relevant details, so we can investigate your claim.

\section{OPEN ACCESS}




\title{
Why do firms issue convertible bonds? Evidence from the field
}

\author{
Ming Dong, Marie Dutordoir, Chris Veld*
}

November 18, 2016

\begin{abstract}
We use in-depth interviews with top corporate executives to examine why companies issue convertible bonds. We find that firms issue convertibles when they perceive these securities to be a cheaper form of financing than straight bonds and equity. A large-sample analysis of security offerings confirms this insight by highlighting feature-adjusted yield spreads as a significant determinant of the choice between convertibles and straight bonds, and equity misvaluation as a significant determinant of the choice between convertibles and equity. Our interviews also allow us to verify individual convertible bond theories. We obtain evidence for the theory that convertible bonds are more suitable than straight debt when management and investors disagree about the riskiness of the firm. However, risk shifting, sequential financing, and backdoor equity theories receive little or no support. Finally, our interviews provide strong evidence for the impact of investor demand and financial intermediaries on convertible bond issuance decisions, two factors under-explored by previous studies.
\end{abstract}

JEL: G32, G13, G24

Keywords: Convertible Debt, Interviews, Market Misvaluation, Investor Demand, Hedge Funds, Investment Banks

* Ming Dong is from Schulich School of Business, York University, Toronto, M3J 1P3, Canada; e-mail: mdong@ssb.yorku.ca; phone: 1 (416) 736-2100 ext. 77945. Marie Dutordoir is from Alliance Manchester Business School, Manchester, M15 6PB, United Kingdom; e-mail: marie.dutordoir@mbs.ac.uk; phone: 44 (0161) -2753936. Chris Veld is from the Monash Business School at Monash University, Caulfield Campus, 900 Dandenong Road, Caulfield East 3145, Melbourne, Australia; E-mail: chris.veld@monash.edu; phone: 61 (03) 99034142. Part of the research for this paper was completed when Chris Veld was affiliated with the University of Stirling and the University of Glasgow and when he was visiting the University of Melbourne and the University of Tampa. We are grateful to all corporate executives who agreed to be interviewed for this study. We thank Zvika Afik, Hank Bessembinder, Michael Brennan, Francesco D’Acunto, Jean-Pierre Fenech, Eileen Fischer, Campbell Harvey, David Hirshleifer, Stuart Hyde, Marcus Ingram, Nadia Massoud, Joseph Mohr, Anna Nadolska, Roger Otten, Joao Quariguasi, Gordon Roberts, Chris Robinson, Anna Samsonova, Norman Strong, Sheridan Titman, John Vaz, Yulia Veld-Merkoulova, Fiona Wilson, and participants at the 2011 European Financial Management Association conference, the 2011 Multinational Finance Society conference, the 2011 Western Economic Association International conference, the $24^{\text {th }}$ Australasian Finance and Banking conference, the 2013 Financial Management Association conference, the 2013 Northern Finance Association conference, and seminars at University of St. Andrews, University of Exeter, University of Maastricht, Simon Fraser University, University of Stirling, and University of Tampa for helpful comments and suggestions. Special thanks go to Ivo Welch (the editor) and two anonymous referees for their very helpful comments and suggestions. We also gratefully acknowledge the research assistance of Andréanne Tremblay, Shiu-Yik Au, and Neeru Chaudhry, the assistance of Amina Abbas Gheewala, Donna McKendrick, and Jessica McKinley in transcribing the interviews, and the financial support of the Social Sciences and Humanities Research Council of Canada (SSHRC), the Institute of Chartered Accountants of Scotland, and the Carnegie Trust for Universities of Scotland. 


\section{Introduction}

Convertible bonds are an important security class. U.S. corporations raised $\$ 801$ billion in convertibles from January 1980 to June 2014, representing $12 \%$ of total U.S. securities issuance volume. ${ }^{1}$ Some theories argue that convertible bonds mitigate agency costs (Green, 1984; Mayers, 1998), while others argue that convertibles alleviate adverse selection costs caused by uncertainty about firm risk (Brennan and Kraus, 1987; Brennan and Schwartz, 1988) or firm value (Stein, 1992). A substantial body of quantitative studies (e.g., Lewis et al., 1998, 1999, 2001, 2003; Chang et al., 2004; Dorion et al., 2014) and survey studies (Graham and Harvey, 2001) has empirically tested predictions generated by these theories. The evidence, however, is largely inconclusive, and the motives for firms to issue convertibles are still not well understood. $^{2}$

Our aim is to gain a deeper understanding of convertible bond issuance motives by adopting a field study approach consisting of in-depth interviews. We conduct 21 semistructured interviews with top executives of corporations in Australia, Canada, the United Kingdom (U.K.), and the United States (U.S.) that have issued convertible bonds. Apart from the seminal study of Lintner (1956) on dividend payout policies, the Finance literature contains few interview studies. ${ }^{3}$ This contrasts with an abundance of interview-based research in some other business fields, such as Accounting, Marketing, and Strategy.

While we acknowledge the well-documented limitations of interviews such as small sample size, we think they provide insights into convertible bond issue motives that are difficult to obtain with other methods. The two main advantages of interviews are the following. First,

\footnotetext{
${ }^{1}$ This total issuance volume number is based on a sample of convertible bonds issued by non-financial and nonutility corporations obtained from SDC Platinum. Offering proceeds (including any over-allotted amounts) are expressed in June 2014 U.S. dollars using quarterly U.S. Consumer Price Index data. We use the same approach to calculate aggregate straight bond and equity volumes over the same period.

${ }^{2}$ See Dutordoir et al. (2014) for a detailed overview of convertible bond theories and empirical findings.

${ }^{3}$ Notable exceptions are Brav et al. (2005) and Graham et al. (2005), who use interviews to aid the interpretation of their surveys on payout policies and corporate financial reporting, respectively.
} 
interviews allow us to identify motives for convertible bond issuance that are not covered by existing theoretical frameworks, by asking managers to describe, in their own words, why they issued convertible bonds. Second, interviews enable us to engage in real-time dialogue with corporate managers and ascertain to what extent they support prevailing convertible bond rationales.

A key finding emerging from our interviews is that firms issue convertibles when they perceive these securities to be a less costly form of financing relative to straight bonds and equity. Convertible issuers in our interview sample tend to first rule out equity, typically because they perceive their equity to be undervalued by the market at the time of issuance. They then weigh convertibles against straight debt and choose convertibles if they perceive the former instruments to be less costly.

Having obtained the key insight that firms weigh the cost of convertibles against the cost of straight bonds and equity, and choose the security they perceive to be least costly hereafter referred to as the 'lowest cost security' hypothesis — we test this hypothesis in a large sample of 15,805 U.S. convertible, straight bond, and (seasoned) equity issues during 19802014. We use the security design feature-adjusted yield spread between straight bonds and convertibles ('residual yield spread') as a proxy for the cost of straight bonds relative to convertibles. We use equity (mis)valuation, proxied by the book-to-market ratio, as a proxy for the cost of equity. In the full sample, we find that the likelihood of convertible relative to straight bond issuance increases with the residual yield spread, and the likelihood of convertible relative to equity issuance increases with the cost of equity. These results are consistent with the lowest cost security hypothesis.

We conduct two split-sample tests to further connect our security choice test results with our interview results. First, since the interviews suggest that convertible bond issuers face varying degrees of financial distress costs, we split the sample into investment grade and non- 
investment grade firms. On the one hand, we can expect the convertible issuance decision to be less sensitive to the yield spread for distressed firms given the lack of financial flexibility of these firms. On the other hand, distressed firms ought to be more concerned about the cost of financing and their decision to issue convertibles may be more sensitive to the yield spread. Consistent with the latter prediction, we find that the residual yield spread has a significant impact on the convertible versus straight bond choice only for issuers with a non-investment grade rating.

Second, we conduct a split-sample analysis of convertibles designed to be more debt-like (with a conversion premium higher than the sample median) and convertibles designed to be more equity-like (with a conversion premium lower than or equal to the sample median). Our motivation for this analysis is the following. Both our interviews and theory (Kim, 1990) suggest that when firms believe the market is undervaluing their equity at the time of issuance, they prefer to set a higher conversion premium in the convertible offer in order to reduce share dilution when conversion occurs. We therefore use the conversion premium as a proxy for the degree to which the firm believes its stock is undervalued by the market at the time of issuance (henceforth shortened to 'perceived equity undervaluation').

We find that, for debt-like convertibles, the likelihood of convertible relative to straight bond issuance increases with the residual yield spread, while the likelihood of convertible relative to equity issuance is not affected by the cost of equity. This result suggests that firms who perceive their equity as undervalued (and therefore use a debt-like convertible design) rule out equity first and mainly choose between convertibles and straight bonds, which is consistent with the answers we obtain from most of our interview firms. In contrast, for equity-like convertibles, the likelihood of convertible relative to equity issuance increases with the cost of equity, while the likelihood of convertible relative to straight bond issuance is unaffected by the residual yield spread. This result suggests that firms who do not perceive their equity to be 
undervalued by the market (and therefore use an equity-like convertible design) mainly choose between convertibles and equity. Hence, our large-sample regression analysis not only confirms our interview findings that firms attempt to issue the lowest cost security, but also helps provide a more comprehensive picture of security choice.

Having established the importance of relative cost considerations in the convertible bond issuance decision, we proceed to use our interviews to verify the validity of the most important theories of convertible bond issuance. One problem with the existing empirical evidence is that the distinction between different convertible debt issuance rationales is subtle, and therefore hard to capture in large-sample quantitative tests or surveys. Key variables used in quantitative studies such as stock return volatility and total assets potentially proxy for multiple factors. This makes it hard to assess which convertible bond rationale best fits the data. Survey responses, in turn, are usually very concise, and pre-set survey questions may impose a structure that does not resonate with respondents. Interviews allow us to present a more elaborate description of convertible bond theories to respondents, and verify to what extent they agree with individual theories. Our interviews provide support for the risk uncertainty theory of Brennan and Kraus (1987) and Brennan and Schwartz (1988): 10 out of 18 respondents state that they chose convertibles over straight bonds because the firm and outside investors disagree about the firm's volatility. Conversely, we obtain limited or no support for theories suggesting that firms use convertibles to avoid risk shifting behavior (Green, 1984), obtain sequential financing (Mayers, 1998), or obtain backdoor equity (Stein, 1992).

Finally, whilst traditional convertible bond rationales and empirical studies focus on firmspecific (demand side) issuance determinants, our interviews allow us to examine the importance of supply side factors and financial intermediaries. We find strong evidence that issuers time their offerings for periods of high investor appetite for convertible bonds, and rely on their investment banks to help identify such periods. Other important players in today's 
convertible bond markets are hedge funds, which act as major buyers of new issues (Brown et al., 2012). Our interviews allow us to assess firms' attitudes towards these capital providers. We find that, while issuers appreciate the liquidity-enhancing actions and fast buying decisions of hedge funds, they dislike the uncertainty resulting from the arbitrage-induced short-selling transactions of the funds.

The remainder of this paper is structured as follows. Section 2 outlines the data. Section 3 provides managers' spontaneously-cited issuance motives. Section 4 cross-checks the results in Section 3 through a large-sample security choice test. Section 5 examines the validity of traditional convertible bond rationales. Section 6 documents the impact of investor demand and financial intermediaries on convertible bond issuance decisions. Section 7 concludes.

\section{Data}

In this section, we describe the sample used in our interview analysis. We identified potential interviewees from a list of all convertible bonds issued by companies domiciled in Australia, Canada, the U.K., and the U.S. between January 1, 2005 and February 1, 2011 obtained from Thomson ONE Banker's Global New Issues Database. These four countries have wellestablished, reasonably-sized convertible bond markets, providing us with a sufficiently large pool of firms to contact for interviews. Moreover, all four countries are English-speaking, which reduces potential misinterpretation of interview answers. We restricted our sample to relatively recent offerings because the corporate executives involved in such offerings were more likely to still be employed in the company and have a good recollection of their issuance motives.

Consistent with other empirical studies of convertible debt (e.g., Henderson and Tookes, 2012), we discarded exchangeable bonds and mandatory convertibles from the sample. We also removed convertible preferred stock as well as convertibles with a maturity shorter than one 
year. This procedure left us with 524 Australian, 688 Canadian, 83 U.K., and 1,834 U.S. convertibles. To keep travel costs manageable, we limited our sample to Australian companies based in the Greater Melbourne area, Canadian companies based in the Greater Toronto area, and U.K. companies based in London, the Midlands, or Scotland.

These geographical requirements left us with a pool of 44 potential face-to-face interview participants (11 in the U.K., 14 in Australia, and 19 in Canada). We contacted these companies with a letter addressed to the company CFO. In a few cases in which we could not identify the $\mathrm{CFO}$, we addressed the letter to the CEO, the Chair, or an Investor Relations manager identified from the company website. If we did not obtain an answer within one week, we followed up with a combination of telephone calls and e-mails. This procedure left us with a sample of 14 interview participants, yielding a response rate of $31.8 \%$. The response rate was highest in the U.K. (six companies, or 54.5\%), followed by Canada (five companies, or 26.3\%), and Australia (three companies, or $21.4 \%$ ).

We then randomly selected 110 U.S. convertible issuers from our data set to be contacted with a telephone interview request. Using a combination of regular mailing, telephone calls, and e-mails, we secured seven interviews with U.S. executives from this list, yielding a response rate of $6.4 \%$. We conducted all but one of the interviews with U.S. managers by telephone. Gillham (2008) argues that telephone interviews present the same important advantages as face-to-face interviews, such as the fact that misunderstandings can be easily clarified. All interviews with convertible bond issuers took place between January 2010 and May 2011.

Our total sample comprises 21 firms. Eight interviewees agreed for their company to be named. Table 1 describes the convertible bond issuance years, the names of companies that 
agreed to be named, and the job titles of interviewees for those companies that did not agree to be named. ${ }^{4}$

$<<$ Please Insert Table 1 here $>>$

Since two firms made two offerings over the research period, the 21 firms in our sample are responsible for 23 convertible bond offerings. For these multiple issuers, we focus on their most recent offering. The average (median) time between issuance and interview dates in the sample is 1.90 (1.77) years. Hence, all of the convertibles except one were still outstanding at the moment of the interview. The sample companies cover a wide range of industries such as Metal and Mining (3), Communications (4), and Security and Commodities Brokers (3) (not tabulated).

The consensus regarding the required number of interviews for an interview study is that the researcher should continue to expand the sample until additional interviews provide few new insights (Eisenhardt, 1989). In our study, we reached this point well before the $21^{\text {st }}$ interview. Our interviewees' cited motives for issuing convertibles are remarkably similar across time, firms, and countries, with variations only in detail, as we further discuss in Section 3.1. Our sample of 21 interviews is similar in size to samples used in the few other interviewbased Finance studies. For example, Lintner (1956) conducts 28 interviews, Brav et al. (2005) 23 interviews, and Graham et al. (2005) 20 interviews. McCracken (1988) suggests that an interview sample of eight is often sufficient to obtain reliable results.

Table 2 provides the mean and median values of firm characteristics (obtained from Datastream, and measured at the fiscal year-end before the convertible bond issuance date) and of convertible-specific characteristics (obtained from Thomson ONE Banker).

$<<$ Please insert Table 2 here $>>$

\footnotetext{
${ }^{4}$ When we name the issuing company, we do not show the interviewee's position. The reason is that we only obtained consent to mention company names, not interviewees' names. Providing interviewees' job positions would make them easily identifiable.
} 
We do not report minimum and maximum numbers to obscure identification of those companies that did not consent to be named. The sample firms tend to have low profitability (median return on assets close to zero), and a relatively low book-to-market ratio (median of 0.32). Differences between the means and the medians of total assets illustrate that most issuers are small companies, with a few larger firms as the exception. The characteristics of our sample firms are similar to the typical profile of convertible bond issuers in quantitative studies of convertible issuance (e.g., Lewis et al., 1998, 1999, 2003).

We also calculate wealth effects associated with the announcement of the convertible bond issues using a standard event study methodology (market model regressions). The average three-day Cumulative Abnormal Return (CAR) is $-2.5 \%$ for the sample, which is consistent with stock price reactions reported by previous studies (Dutordoir et al., 2014). The other issuespecific characteristics are also largely consistent with descriptive statistics reported by other studies (e.g., Duca et al., 2012). But notably, convertible issuers in our interview sample tend to have a high conversion premium relative to the typical issue (median of $29.04 \%$, compared with a sample median of $25 \%$ for U.S. issues during 1980-2014). We discuss a possible interpretation of this high conversion premium in Section 3.2.

We conducted the field and telephone interviews according to the scientific protocols outlined in Gillham (2008) and Kvale and Brinkmann (2009). Appendix A provides a detailed description of the interview design and execution. Our interview questions fall into three broad categories. We started each interview with an open question on issue motives. We proceeded with a set of questions on the main convertible bond theories in the literature. Finally, we asked about the importance of investor demand and financial intermediaries. 


\section{Managers' spontaneously-cited issuance motives}

At the start of each interview, we asked managers to describe, in their own words, why they issued convertible bonds. Table 3 provides a detailed overview of the executives' answers to this open question.

$$
<<\text { Please insert Table } 3 \text { here }>>
$$

Most executives started their answer by outlining the sequence of their security choice and elimination process, and by mentioning the perceived advantages of convertibles over straight debt and equity. We discuss the main types of convertible bond issuers emerging from these answers in Section 3.1. Most of the convertible issuers in our sample ruled out equity first. We discuss their motives for not issuing equity in Section 3.2. One popular viewpoint on convertibles is that managers issue these securities because they are deluded about their true cost (Brennan and Schwartz, 1988). Section 3.3 discusses to what extent this so-called free lunch perspective on convertible bonds is reflected in managers' answers to the open question. Finally, Section 3.4 summarizes the results of interviews with non-issuers that we executed as a robustness test.

\subsection{Convertible bond issuer types emerging from the open question}

When analyzing the interview transcripts, we noted that spontaneously-cited reasons for issuing convertibles fall into three broad categories, based on the overall content of the answers. Panel A of Table 4 describes these categories.

$$
<<\text { Please insert Table } 4 \text { here }>>
$$

The three types of convertible issuers share the feature that they ruled out equity financing either because they believed their stock had a low valuation (either undervalued by the market, or not valued highly enough to warrant an equity offering), or because they wanted to avoid 
diluting share value. ${ }^{5}$ The largest group (13 firms in total, corresponding to 14 convertible bond issues since one firm made two separate issues) seriously considered issuing straight debt, but chose convertibles because they considered straight debt to have too high a coupon rate at the time of financing. We label this category 'coupon' issuers. We prefer to use the term coupon over yield, because most interviewees used that term in their responses. A second category, labeled 'covenant' issuers (three out of 21) mentioned that an important reason for preferring convertible bonds to straight bonds is that the former securities offer fewer restrictive covenants, and therefore more flexibility. As one covenant firm executive stated: "One of the things that was of interest to me personally was a lighter covenant deal because I thought that I didn't want to be constrained by a lot of heavy covenants, particularly on capital expenditures or things that might impede our growth." A third category, labeled 'constrained' issuers (four out of 21), had urgent financing needs but did not have any access to bank debt or straight bonds at the moment of financing due to their high-risk or negative-cash flow operations. One constrained firm executive stated: "To be honest, you would take whatever you could get. It was a question of securing the funds which is always a life or death question for us, rather than contemplating that we had a range of alternatives to choose from."

The remaining company in our sample used convertibles to finance the repurchase of a portion of its equity, which it perceived to be undervalued. We label this a 'repurchase' firm in Tables 3 and 4. The company's main motive for financing the stock repurchase through issuing securities instead of through its ample excess cash reserves was tax avoidance. Most of the firm's cash was generated outside its country of domicile, and repatriating the cash would have cost more in taxes than issuing securities. Similar to coupon issuers, the company reasoned that coupon payments on straight bonds would be too high for it to take the straight debt route.

\footnotetext{
${ }^{5}$ We further explore these arguments for ruling out equity in Section 3.2.
} 
However, it differs from the coupon category of issuers in that its stock repurchase automatically ruled out stock issuance as a viable security choice.

We conclude that most interviewed firms consider straight debt as the more serious alternative to convertibles. The three main categories primarily seem to reflect varying degrees of financial distress costs, with covenant issuers being least restricted by financial distress risk, coupon issuers exhibiting intermediate risk, and constrained firms suffering from strong debt constraints due to excessively high financial distress risk. Although most covenant and constrained firms did not explicitly mention coupon differences between convertibles and straight bonds as a driver of their security choice, this was probably an important consideration for these firms as well. The constrained firms can in fact be viewed as a special case of the coupon category in the sense that the coupon rate on their straight bonds would have been excessively high. Finally, the repurchase firm is similar to the other three categories in that it ruled out straight debt because of cost concerns, and it also perceived its equity to be undervalued at the time of issuance.

\subsection{Perceived stock misvaluation and the motives for ruling out equity}

As discussed in Section 3.1, most of the interviewed firms ruled out equity in a first step of their security choice process. In this section we discuss their motives for doing so in more detail, and connect these motives to theory.

Executives' main cited reason for not issuing equity is that they considered their stock to be undervalued by the market at the moment of issuance. Ten managers explicitly mentioned that their shares were underpriced at issuance. An additional four managers stated that issuing equity would have been too dilutive to shareholders. In an efficient market, there should be no shareholder value dilution if a company issues equity to fund a positive Net Present Value project. Therefore, managers' argument that equity issuance would be dilutive indicates that 
they perceived their shares to be underpriced. The equity undervaluation concerns emerging from the interview answers are consistent with survey results of Graham (1999) who finds that more than two-thirds of firms believe that their equity is undervalued by the market.

Despite these undervaluation concerns, a careful analysis of executives' answers to the open question about issue motives suggests that their reluctance to issue equity is not driven by adverse selection concerns, as would be the case according to the Myers and Majluf (1984) theory. In particular, none of the interviewees expressed any major concern with the possible negative stock price effects of equity offering announcements, which is the key signaling problem underpinning the Myers and Majluf (1984) adverse selection framework.

Our findings thus suggest that managers exhibit pecking order behavior (Table 4, Panel A), but that this behavior is not driven by an adverse selection problem resulting from asymmetric information about firm value. That is, managers seem reluctant to issue undervalued equity, but they do not seem to believe that such equity issuance would further depress stock prices, as would be the case under the Myers and Majluf's (1984) adverse selection theory. As such, our results are consistent with Graham and Harvey (2001: p. 222) who argue that: "[A]symmetric information does not seem to cause the importance of these [pecking-order] factors, as it should if the [Myers-Majluf] pecking-order model is the true model of capital structure choice.”

The interviewees' preferences for convertibles over equity could be consistent with the framework of Heaton (2002), which predicts a pecking-order type behavior for managers who are over-optimistic about their own firm value, and with the empirical finding of Malmendier et al. (2011) regarding the impact of managerial overconfidence on capital structure. In line with such interpretations, Lee and Loughran (1998) and Lewis et al. (2001) document negative abnormal stock returns over the years following convertible bond issuance. 
Consistent with the issuers' perception of their stocks being undervalued by the market, several of our interviewees expressed the need to have a high conversion premium to reduce share dilution in the event of conversion. As noted earlier, the conversion premiums in our interview sample tend to be high, with 16 out of 21 convertibles having a premium at or above 25\% (the U.S. sample median during 1980-2014). Seven interviewees explicitly mentioned the ability to set a high conversion premium in order to reduce equity dilution as a positive determinant of their decision to choose convertible bonds. In addition, five issuers told us that they used a call spread overlay to boost the effective conversion premium, thereby reducing share dilution from conversion. ${ }^{6}$

Finally, it is worth mentioning that while most of the interviewed firms explicitly ruled out equity issuance, five interviewees made it clear that if the stock price had been substantially higher, they would have seriously considered issuing equity.

\subsection{The free lunch perception of convertible debt}

The free lunch perception of convertible debt holds that convertibles are a cheaper form of financing than both straight debt and equity in all possible contingencies. As Brennan and Schwartz (1988) argue, this perspective on convertible debt is misconceived. Equity would have been better for the firm than convertible bonds if the stock performs badly, since the firm would then not have to pay fixed coupons on the convertible bonds. Straight debt, in turn, would have been better for the firm than convertible bonds if the stock performs well, since shareholders would then not have to share their residual claim with convertible bondholders. Hillier et al. (2013: p. 673) suggest that the free lunch misconception of convertibles is still widespread among practitioners: "Probably there is no other area of corporate finance where

\footnotetext{
${ }^{6}$ A call spread overlay involves buying calls with the same conversion price as the convertible, and selling warrants with a higher conversion price to synthetically increase the effective conversion price.
} 
real-world practitioners get as confused as they do on the reasons for issuing convertible debt."

However, managers' answers to the open question indicate that they are very well aware of the fact that the convertible bond coupon is lower because of the conversion privilege. As one manager stated: "Obviously, there is an equity element in there, which is attractive to investors and that is why you get the cheap coupon.” Managers also realize that the decision to convert lies with the holder of the convertible bonds and not with themselves. One of the executives argued: "I assume that it won't convert, because that is the cautious thing to do." In an untabulated result, five executives mentioned that convertibles should constitute only a limited fraction of the issuers' capital structure, due to the fact that conversion may occur at a non-optimal moment for the firm.

\subsection{Interviews with issuers of other security types}

The 21 interviews discussed above are all with convertible bond issuers. As a result, the key findings from the interviews may reflect opinions of managers who are not fully aware of the limitations of convertibles. To alleviate this concern, we interviewed a set of companies who are similar to actual convertible bond issuers but instead issued straight debt or (preferred) equity over our sample period 2005 to 2011 . To select these issuers, we downloaded straight bond and seasoned equity issues from Thomson ONE Banker for each of the four sample countries. We then matched each convertible bond issuer in our interview sample with two companies that issued straight bonds or seasoned equity but no convertibles, have the same three-digit SIC-code as the convertible bond issuer, and are its closest matches in terms of asset size and credit rating (among all suitable candidates). For brevity, we label these firms 'non- 
issuers' in the remainder of this subsection. We secured six interviews with non-issuers. ${ }^{7}$ The interviews started with the question why these companies had opted for the chosen security types, and then proceeded with the question why they did not issue convertible bonds instead.

Two of the non-issuers said that they did not use convertibles because they were able to attract straight debt at a reasonable cost. As one of them argued: "I think that's why you'll find that world-class issuers haven't had to use convertibles because their access to senior debt has been cheap enough without having to lower the costs through selling the call option because I think that's the only reason you do it, to lower the cost of senior debt." For that reason, the same respondent's opinion about convertibles is: "I call it the security of the desperate and dateless." Furthermore, three of the non-issuers highlighted equity dilution as a key concern driving their security issuance decision. As noted earlier, such concerns should be stronger for firms that perceive their equity as undervalued.

Overall, these interviews with non-issuers corroborate our baseline finding that firms base their convertible issuance decisions on the costs of convertibles relative to straight bonds and equity.

\section{The drivers of convertible issuance: A security choice analysis}

Our interviews yielded the main insight that firms use convertible bonds when they perceive these securities to be a cheaper form of financing than debt or equity. In this section, we test the validity of this 'lowest cost security' explanation for convertible bond issuance by running a quantitative test of the determinants of firms' choice between convertible bonds, straight bonds, and equity. We also execute two split-sample tests to better connect the security choice results to the interview results. The remainder of this section discusses the methodology

\footnotetext{
${ }^{7}$ Three of these non-issuers were based in the U.S., two in Australia, and one in the U.K. Two non-issuers issued both straight bonds and equity, one issued only straight bonds, two issued only equity, and one issued only preferred equity. Four of the interviews were conducted by telephone and two were conducted face-to-face.
} 
and results of the security choice analysis, and links these results with those from the interviews.

\subsection{Methodology}

We collect a sample of convertibles issued by U.S. firms between January 1, 1980 and June 30, 2014 from SDC Platinum's Global New Issues database (henceforth SDC). We obtain a raw sample of 5,601 issues. From that sample we remove issues made by financial firms (SIC codes starting with 6) and utilities (SIC codes starting with 49), convertible preferred stock and unit offerings, and issues with a non-positive conversion premium. For convertible bond tranches offered on the same day by the same firm, we sum the issue proceeds and consider the design characteristics of the main tranche.

We also obtain straight bond and seasoned equity (henceforth equity) samples from SDC. For the straight bond sample, we require that the offering maturity is at least one year, the issuer is a publicly listed company, and the offering does not represent a medium term note takedown. The raw straight bond sample consists of 27,990 issues. For the equity sample, we require that the offering is not an IPO, does not entirely consist of a sale of existing shares, and does not represent a unit offering. The raw equity sample consists of 17,540 issues. We clean these samples using similar exclusion criteria as for the convertible bond sample, e.g. we remove offerings made by financials and utilities and we again aggregate issue tranches offered by the same firm on the same date into one offering.

We subsequently remove security offerings for which we cannot retrieve the required firmspecific variables from Compustat and CRSP. We thus obtain a convertible bond sample of 2,113 offerings, a straight bond sample of 7,012 offerings, and an equity sample of 6,680 offerings, or 15,805 security offerings in total. 
Our interviews suggest that the spread between yields on straight and convertible bonds positively affects firms' decisions to issue convertibles instead of bonds, as convertibles become relatively more attractive in times when this yield spread is higher. We therefore use the yield spread between straight bonds and convertible debt as a proxy for the cost of straight bonds relative to convertibles. One potential criticism of using a simple unadjusted yield spread is that it does not control for security design and issuer features affecting yield to maturity. We address this issue by defining the residual yield as the component of the yield to maturity that is orthogonal to a set of variables identified by the literature as determinants of cross-sectional variations in (convertible) bond yields (Fang, 2005; Reisel, 2014). We then take the difference in average residual yield spreads for bonds and convertibles, lagged one quarter relative to the issue quarter, and label this measure residual yield spread. Fluctuations in the residual yield spread could be driven by changes in investors' appetite for the two securities, which could in turn create catering incentives for companies. Appendix B includes a more detailed definition of residual yield spread, as well as the other explanatory variables included in the security choice analysis.

We use the book-to-market ratio of equity $(\mathrm{B} / \mathrm{M})$ as a proxy for the misvaluation of the issuing firm's stock, in line with Baker and Wurgler (2002, 2004), Jenter (2005), Dong et al. (2006), and Dong et al. (2012). A higher B/M value indicates a lower stock valuation level and therefore a higher cost of equity. ${ }^{8}$

Next to these two key proxies), our security choice analysis includes stock return volatility, return on assets, leverage, cash, age, and firm size as standard proxies for firm-specific financing costs. These variables are related to asymmetric information, agency costs, financial distress costs, and growth stage (Bayless and Chaplinsky, 1991; Jung et al., 1996; Lewis et al.,

\footnotetext{
${ }^{8}$ Our key proxy for the cost of equity, book-to-market, might also act as an inverse proxy for growth opportunities (Dong et al., 2012). Despite this limitation we believe that B/M is a suitable proxy for our research, as it should at least be significantly correlated with equity misvaluation.
} 
1999, 2003; Dutordoir and Van de Gucht, 2007, 2009; DeAngelo et al., 2010). In addition, our analysis includes standard proxies for economy-wide financing costs (Alexander et al., 1979; Bayless and Chaplinsky, 1991; Choe et al., 1993; Mann et al., 1999; De Jong et al., 2011). Detailed definitions are presented in Appendix B. All macroeconomic variables are calculated as growth rates over the quarter preceding the issuance quarter.

Similar to Dong et al. (2012), we use a multinomial probit model to estimate the determinants of firms' choice between convertibles, straight bonds, and equity, because the issue under investigation fails to satisfy the so-called 'independence of irrelevant alternatives' (IIA) property of the multinomial logit model. In particular, a Hausman test rejects the null hypothesis of IIA for our baseline analysis with a $\chi^{2}$ value of 263.67 ( $p$-value $<0.001$ ). The multinomial probit model does not require the IIA property and is therefore more appropriate for our research purposes. Results remain similar when we use a multinomial logit model instead. ${ }^{9}$

\subsection{Results}

The multinomial probit model simultaneously considers convertibles, bonds, and equity. Similar to a multinomial logit model, its output consists of two pairwise regressions: one for the choice between convertibles and bonds, and one for the choice between convertibles and equity. Panel A of Table 5 presents the baseline results of the security choice analysis. A positive coefficient indicates a higher likelihood of choosing convertibles over bonds (Column 1) or equity (Column 2).

\section{$<<$ Insert Table 5 here $>>$}

We find a positive impact of the residual yield spread on the likelihood of choosing convertibles over bonds, and a positive impact of $\mathrm{B} / \mathrm{M}$ on the likelihood of choosing

\footnotetext{
${ }^{9}$ Results of all unreported robustness checks are available upon request from the authors.
} 
convertibles over equity. Together, these findings are consistent with the prediction that firms choose convertibles over bonds and equity based on relative costs considerations. That is, they prefer convertibles over bonds in times when bonds are more costly in terms of yield to maturity, and convertibles over equity when equity is undervalued and therefore more expensive. ${ }^{10}$

We also examine whether managers can time convertible bond issues to occur at peak stock return volatility by including volatility change, measured as the difference between preissuance and post-issuance stock return volatility. ${ }^{11}$ Since convertibles embed a call option, they should be priced more favorably when stock return volatility is high. If managers successfully time convertibles to occur prior to decreases in volatility, we should find a positive impact of volatility change on the likelihood of issuing convertibles. However, we do not find a significant impact for this variable, whilst the other results remain unchanged. We conclude that, while firms seem to consider the cost of convertibles relative to straight bonds and equity in their issuance decision, they seem unable to time convertibles to volatility peaks.

We conduct two split-sample analyses to connect the security choice results with the insights obtained from the interviews. One insight emerging from the interviews is that convertible debt issuers have varying degrees of financial distress costs, with constrained firms representing the issuers closest to financial distress. On the one hand, financially constrained firms may exhibit weaker market timing behavior, since they have less flexibility to wait for favorable issuance conditions (Korajczyk and Levy, 2003). On the other hand, quasi-distress firms may be more sensitive to yield spreads with straight bonds than other firms, since issuing straight bonds would be highly costly to them. Thus, it is unclear a priori whether yield spreads

\footnotetext{
${ }^{10}$ In unreported tests, we confirm that our baseline results are robust to alternative specifications such as using industry-adjusted B/M (where industry is defined using three-digit SIC codes) instead of raw B/M, including offer proceeds in the regressions, and removing firms that make offerings of different security types within a given year.

${ }_{11}$ Appendix B provides a more detailed definition. The same result holds when we use other specifications of volatility change (e.g. with volatility measured over 200 rather than 60 trading days before and after issuance).
} 
should have a weaker or stronger impact on firms with stronger debt constraints. The interview sample does not allow us to formally test this question due to its small size, but we can test it with the larger security offering data set. We use S\&P long-term issuer credit ratings obtained from Compustat as a summary measure of financial distress costs and split the data set into issuers with non-investment grade rating (rated lower than $\mathrm{S} \& \mathrm{P} \mathrm{BBB}$, or non-rated) or investment grade rating. ${ }^{12}$ Table 5, Panel B provides the results. For non-investment grade issuers, we find a significant impact of residual yield spreads on the convertible bond versus straight bond tradeoff (Column 1a), whilst for investment grade issuers we do not find a significant impact (Column 1b). This finding suggests that costs relative to straight bonds matter more for issuers with stronger debt constraints.

Another insight emerging from the interviews is that most interviewed firms believe that their equity was undervalued by the market at the moment of issuance. Thus, the finding that convertible issuers rule out equity first and mainly consider yield differences with straight bonds may be conditional on the high level of perceived equity undervaluation of our interviewees. Our large security sample allows us to execute a split-sample analysis for convertible issuers with different degrees of perceived equity undervaluation, thereby offering a more complete test of the lowest cost security hypothesis for convertible bond issuance. A challenge for this subsample test is to get a valid measure of managers' subjective sense of equity undervaluation. However, as discussed in Section 3.2, our interviews suggest that firms tend to set a high conversion premium to combat the share dilution cost when they perceive equity to be undervalued by the market at the time of issuance. Consistent with this behavior,

\footnotetext{
${ }^{12}$ We use a binary split based on investment grade rating rather than trying to identify three issuer types (covenant, coupon, and constrained) as in our interview study. The reason is that it is empirically very hard to disentangle these three groups based on quantitative firm-specific information. Within our interview sample, six or $28.57 \%$ of the convertibles have an investment grade rating (we did not get issuer ratings for these issues as this information is hard to obtain for non-U.S. bonds; issue ratings should be highly correlated with issuer ratings). Five of these investment grade offerings are made by coupon firms. Unsurprisingly, none of the constrained firms has investment grade convertibles. The remaining investment grade convertible belongs to the repurchase firm.
} 
Kim (1990) predicts that firms with more favorable earnings expectations will set a higher conversion price on their convertibles to reduce share price dilution upon conversion. We therefore use the conversion premium as a proxy for the degree to which the firm perceives its equity as undervalued by the market.

Table 5, Panel C provides the results of a split-sample analysis, with debt-like convertibles identified as convertibles with a conversion premium higher than the sample median of $25 \%$, and equity-like convertibles as the remainder of the sample. The straight bond and equity samples are the same as those used in the baseline test in Panel A. Interestingly, for debt-like convertibles, we find a positive impact of residual yield spread and a negative impact of $\mathrm{B} / \mathrm{M}$ on the choice between convertibles and bonds (Column 1a). These findings suggest that debtlike convertible bond issuers choose between convertibles and straight bonds, and both an increase in the yield spread and a reduction in the cost of equity lead to a higher likelihood of convertible issuance. On the other hand, there is no significant impact of $\mathrm{B} / \mathrm{M}$ on the choice between convertibles and equity (Column 2a) for this subset of issuers, suggesting that their security choice is mainly between convertible and straight bonds rather than between convertibles and equity.

Conversely, for equity-like convertibles we do not find a significant impact of the residual yield spread for the convertible versus straight debt choice (Column 1b), whilst B/M has a strong impact on the trade-off between convertible and equity (Column $2 \mathrm{~b}$ ). This subset of issuers thus seems to weigh between convertibles and equity, with a reduction of the cost of equity significantly boosting their likelihood of offering equity instead of convertibles, and the yield relative to straight bonds being a non-binding security choice determinant.

Together, the conversion premium-based split-sample results suggest that firms with high perceived equity undervaluation (translating into a debt-like convertible bond design) mainly use convertibles as an alternative to straight bonds, while firms with lower perceived equity 
valuation (translating into an equity-like convertible bond design) mainly use convertibles as an alternative to equity.

\subsection{Link with interview results}

The security choice results in Table 5 are easily reconcilable with managers' spontaneous answers on the open question why they issued convertible bonds. Consistent with the 'lowest cost security' pattern emerging from the interviews, the full sample results highlight costs of convertibles relative to straight bonds and equity as important determinants affecting the decision to issue convertibles. The split-sample results based on issuer credit ratings and conversion premium allow for an even clearer link with the interviewed firms. The interviews suggested that issuers differ in their magnitude of financial distress costs, but do not allow for a formal test of any link with issue motives due to the small sample size. The security choice results complement and deepen these insights by showing that yield spreads with straight bonds matter only for low-rated, high financial distress costs firms.

As discussed in Section 2, most of the convertible issuers in the interview sample perceive their equity as undervalued by the market. Our finding in Table 5 that these firms mainly consider the cost relative to straight bonds in their issuance decision is perfectly consistent with interviewees' answers discussed in Section 3. These answers suggest that most of our interviewees first ruled out equity, and then decided between convertibles and bonds based on yield spreads.

While the security choice results confirm the insights from our interviews, the split-sample results in Panel B of Table 5 provide a more complete picture as they have a larger representation of convertibles with a more equity-like design. The results suggest that equitylike convertible bond issuers mainly use convertibles as a substitute for equity. This finding is perfectly consistent with the lowest cost security reasoning emerging from the interviews, as a 
lower perception of equity undervaluation should make an equity offering more acceptable. Only five of the convertibles in our sample fall into the equity-like convertible category (conversion premium lower than or equal to $25 \%$ ). However, three of these firms used call spread overlays to boost their conversion premium, making the actual number of equity-like convertibles even smaller. The two remaining issuers (Firm 1 and Firm 16, as denoted in Table 3 ) indeed viewed their equity valuation as fair and did not cite equity undervaluation as a motive for issuance, which is consistent with our assumption that low conversion premiums reflect smaller managerial concerns about equity undervaluation. ${ }^{13}$ Furthermore, as mentioned in Section 3.2, five of our 21 interview firms said they would consider offering equity if their stock prices were higher, consistent with the interpretation that firms choose between convertibles and equity when they perceive their stock valuation to be high.

The security choice analysis has three main limitations relative to the interview approach. First, unlike interviews the security choice test does not allow us to directly test the sequence of security choice decisions (i.e., which security type is ruled out first). ${ }^{14}$ Second, unlike interviews, the security choice approach does not allow a clean test of the validity of individual theories on convertible bond issuance, as the proxies for testing the different theories are largely similar (Dutordoir et al., 2014). For example, the finding in Panel A of Table 5 that convertible bond issuers have higher pre-issue volatility than straight bond issuers is consistent with the risk shifting theory of Green (1984) as well as the risk uncertainty rationale of Brennan and Schwartz (1988). Interviews allow us to test firms' agreement with these theories more precisely. Section 5 provides the results on the validity of convertible bond rationales, obtained through interviews. Third, the security choice test does not allow us to measure the importance

\footnotetext{
${ }^{13}$ Firm 1 issued convertibles in combination with equity, further suggesting the firm did not rule out equity because of equity undervaluation. Firm 16 viewed stock valuation as quite high at the convertible issue time and believed there was limited upside in stock price.

${ }^{14}$ As noted by Gomes and Phillips (2012), adopting a nested approach for security choice modeling would not solve this issue as the nested structure does not rely on an assumption of any timing or sequence of choices.
} 
of investor demand, although fluctuations in residual yields might act as an indirect proxy for such demand. Interviews enable us to ask directly about the importance of investors and intermediaries in driving convertible bond issuance, which we do in Section 6.

\section{The validity of convertible bond theories}

Following up on the open question about issue motives, we examine the validity of the four main theoretical models of convertible bonds provided by the literature. In Section 5.1, we summarize each of these theories and discuss the relevant interview evidence. In Section 5.2, we provide further clarification about the risk uncertainty theory by linking it with the answers on the open questions.

\subsection{Description of theories and interview findings}

According to Green's (1984) risk shifting theory, convertibles are well suited to controlling the risk incentives associated with debt financing. Shareholders of levered firms have an incentive to substitute higher-risk for lower-risk operating and investment policies, even when this may lower the value of the firm as a whole. The conversion option included in convertible bonds enables bondholders to participate in the upside potential of the firm's stock, thereby weakening shareholders' tendency to engage in such harmful asset substitution activities.

The risk uncertainty rationale of Brennan and Kraus (1987) and Brennan and Schwartz (1988) is based on the central assumption that insiders and outsiders agree on the total value of the firm, but disagree on its volatility. As such, they fail to reach a consensus on the value of the firm's straight debt claims. In particular, if managers believe volatility is low and outsiders believe volatility is high, managers will consider their cost of debt to be excessively high. However, a properly designed convertible will be (locally) invariant to risk so that both insiders and outsiders can agree on its value, even though they disagree on the firm's volatility. 
Mayers' (1998) sequential financing theory posits that convertible debt is more suitable for financing a sequence of real options than either short- or long-term bonds. On the one hand, convertibles economize on the transaction costs that would be associated with multiple shortterm debt offerings, since conversion leaves funds inside the firm. On the other hand, unlike long-term bonds, convertibles can overcome free cash flow problems by redeeming funds to bondholders when the investment option turns out to have no value.

While these theories model convertibles as an alternative to straight debt, Stein's (1992) backdoor equity theory models convertible debt as delayed equity financing for firms that have ruled out straight debt because of excessive financial distress costs. Stein's model relies on the Myers and Majluf (1984) adverse selection argument that, when there is asymmetric information about firm value, an equity offering announcement signals to the market that the firm is overvalued, and therefore generates a negative stock price effect. Since convertibles have a smaller equity component, investors are less likely to perceive convertible issuance as a signal of firm overvaluation, thereby reducing adverse selection costs in the form of negative announcement returns.

The backdoor equity and sequential financing rationales both predict that callability is a key feature of convertible bonds, since it enables issuers to force conversion of the bonds into equity if it is optimal to do so. Conversely, risk shifting and risk uncertainty rationales yield no prediction on this design feature.

We presented corporate executives with descriptions of each of these theories and asked whether these theories applied to their own convertible bond issuance. Panel B of Table 4 summarizes the answers. Green's (1984) theory received modest support from only two of the 19 interviewees we checked this theory with. One of the interviewees mentioned that his issuance motives were "far more pragmatic than that." Another executive swiftly dismissed this theory as follows: "I've never seen that in practice, so I throw that thesis out right away. 
The world does not think that way, companies don't think that way, shareholders don't think that way."

Ten out of the 18 executives confronted with the Brennan and Kraus (1987) and Brennan and Schwartz (1988) risk uncertainty theory felt that this rationale applied to their convertible bond offering. Consistent with this rationale, these executives argued that the coupon they would have had to pay on straight debt was too high, because the market believed the companies were riskier than the managers thought. They also stressed the view that the value of convertibles would be less affected by such differences in perceived risk. One of the responses that reflected this view was: "I am going to agree with you, we are saying the same thing. The interest rate on our debt would have been more expensive, and this is because it spoke to sort of the perceived risk of the company, and because of that, you were able to get a more beneficial rate on the convertible. I think that was intuitively one of the reasons we went down that path."

An overwhelming majority (15 out of 18$)$ of the executives presented with a description of Mayers' (1998) rationale stated that their issuance was not driven by sequential financing considerations. A typical response is: “Not that we don't need money until the future for future acquisitions. I don't know what other people would think, but I think nobody has the crystal ball what the reasons will be like in the future. If you are borrowing money today, you'd better like the pricing assuming you don't have future use of the money but the current use is valid."

Consistent with the backdoor equity rationale of Stein (1992), five out of 18 executives agreed that convertibles can serve as a form of delayed equity financing (see, for example, the statement of Firm 8 in Table 3). However, an in-depth analysis of the interview transcripts indicates that their answers do not support several key dimensions of the Stein (1992) theory. First, none of the respondents, including Firm 8, mentioned the adverse signal sent by equity offerings or the associated negative announcement returns as an important factor affecting their 
decision not to issue equity. As discussed earlier, the main reason for the interviewees to rule out equity is that they do not want to dilute shareholder value by issuing already undervalued equity (with the perception of equity undervaluation possibly driven by managerial optimism). Unlike what would be the case under Myers and Majluf's (1984) and Stein's (1992) adverse selection scenarios, our interviewees do not seem to believe that issuing equity would lead to a downward revision in their firm's stock price. ${ }^{15}$

Second, executives' opinions on the use of the call feature in convertible debt are also inconsistent with Stein's (1992) model. Stein (1992) argues that callability is a critical feature of convertible debt, since it enables the issuer to force conversion into equity. However, when we asked managers whether, and if so why, they included a call feature in their offering, cited reasons for including a call feature were mostly related to the costs associated with debt financing, rather than with the flexibility to convert the bond into equity. In particular, most executives mentioned the fact that the call option allows the company to issue debt at a lower cost, or to free up debt capacity to finance investment projects such as acquisitions. The most popular reason for not including a call feature (cited by three companies) is that the firm would not have the necessary cash flows to refund the debt when called. This answer corroborates that the possibility to force conversion into equity does not play an important role in the decision to include a call feature in convertible bonds.

To conclude, we find substantial support for the risk uncertainty rationale and weak support at best for other common theories of convertible bond issuance.

\footnotetext{
15 Our large-sample regression test in Section 4 indicates that when firms perceive equity as highly valued, convertibles act as a substitute for equity. However, even in that case, our analysis suggests that firms' reason for choosing convertible over equity is that equity valuation is not high enough (or cost of equity is not low enough). In contrast, in Stein's (1992) model, firms rule out equity to avoid sending a signal of equity overvaluation.
} 


\subsection{Link with answers to open question regarding risk uncertainty rationale}

Executives' support for the risk uncertainty rationale is consistent with their emphasis on the lower coupon of convertibles in their answers to the open question regarding issuance motives (discussed in Section 3). In particular, the risk uncertainty rationale implies that companies issue convertible bonds when a straight debt offering would be costly because the market overestimates the issuer's risk. However, the risk uncertainty theory of Brennan and Kraus (1987) and Brennan and Schwartz (1988) relies on the assumption that insiders and outsiders agree on the total value of the firm. Thus, if managers consider their debt to be undervalued due to disagreements about firm risk and volatility, this means that their equity should be overvalued. This part of the risk uncertainty theory is not in line with our finding that many of the interviewees expressed strong concerns about equity undervaluation at the moment of issuance voiced in their answer to the open question about issue motives (as discussed in Section 3.2). Thus, while the risk uncertainty theory seems to be able to explain the choice between straight bonds and convertibles, it cannot entirely explain the choice between convertibles and equity, as the latter choice seems mainly driven by undervaluation concerns.

\section{The influence of investors and financial intermediaries}

In addition to questions about convertible motives, our interviews with executives included questions about the role of investors and investment banks. We summarize the results on this question in Panel C of Table 4.

\subsection{The role of investors}

As pointed out by Baker (2009), corporate finance studies have traditionally focused on the corporate supply side, thereby implicitly considering the investor side as a black box with perfectly elastic and competitive demand. A recent strand of the literature shows that corporate 
finance actions can also be influenced through investor demand channels (Faulkender and Petersen, 2006; Leary, 2009; Lemmon and Roberts, 2010). Consistent with the importance of investor demand, 17 out of 21 issuers indicated that they issued convertibles when they felt the convertible bond market was hot. Representative quotes include: "Convertibles are an opportunistic tool”, "Obviously when I am raising cash, if there is no demand for convertibles I won't be selling convertibles. It's like selling ice creams in winter", and: "It is the market. If I want to sell oranges, I have to sell oranges that I know the people want to buy." One executive argued that an appropriate timing of the offering is more important for convertible debt than for straight bonds or bank debt: “It [i.e., the convertible bond market]'s certainly much more risky in terms of if it's open or not because it does fluctuate around and I think terms do move around far more than you would see in the ordinarily bond market and certainly in the bank market. (...) You certainly see plenty of times when the convertible bond market is completely closed and it's just not doable and the terms are definitely much more volatile."

Around the year 2000, the convertible investor population shifted from long-only investors towards convertible arbitrage funds, who tend to buy convertibles and short the underlying stock. During the recent Global Financial Crisis, however, the fraction of convertible arbitrage funds among convertible bond investors sharply declined and long-only investors came back into play. A number of studies analyze the impact of convertible arbitrageurs on convertible bond issuance volume (Choi et al., 2010; De Jong et al., 2013), convertible bond design (Brown et al., 2012; De Jong et al., 2011), and convertible bond announcement and issue date returns (Duca et al., 2012; De Jong et al., 2011; Loncarski et al., 2009). Our study complements these quantitative studies by explicitly asking convertible bond issuers whether convertible arbitrage hedge funds influenced their security choice decisions. Most of the interviewed executives (19 out of 21) indicated that hedge funds were indeed involved as buyers of their convertibles. A substantial number (seven) of executives appreciate the liquidity-providing role of convertible 
arbitrage hedge funds, as well as the fact that these funds can take very fast buying decisions. As one respondent commented: “Don't forget that it is a community that can make a decision in a heartbeat. So, that was one of the reasons why you could announce one of these deals at 9 am and price it at $10.30 \mathrm{am}$, because the hedge funds don't have to see management and do a credit committee, and decide how much they want to buy, which is sort of a process you go through in a regular bond road show, which might take two or three days." On the other hand, a number of executives mentioned that they dislike the uncertainty and the negative stock price effects brought about by the shorting transactions of hedge funds, although they do realize that this shorting-related stock price reaction tends to be short-lived (one interviewee called it " $a$ technical sag”). Some issuers accept the disadvantages associated with hedge fund involvement as a fact of life: "You are always worried about that [i.e., the role of hedge funds], but you can do nothing about that. The whales swim in the sea and you have to swim in the sea too", or: "That was definitely something we thought about and were aware of, but we talked through that phenomenon with our bankers and we thought that it [i.e., the negative price reaction] was going to be a short term blip only and we concluded that we weren't going to let that stop us from doing the transaction." Interestingly, the answers suggest that a substantial number of issuers take actions to mitigate, or at least control, hedge fund involvement. Four firms requested their investment bank to estimate the amount of short selling that would occur if they offered a convertible bond. Five companies mentioned that a high demand for their offering enabled them to allocate only a limited amount to hedge funds, and the remainder of the proceeds to long-only investors. One executive stated that the convertible was deliberately placed with designated (non-hedge fund) buyers, and another executive stated that his company bought back stock from potential arbitrageurs to reduce their incentive to engage in openmarket short selling. The latter finding is consistent with the rationale for convertible bondstock repurchase packages documented in De Jong et al. (2011). 


\subsection{The role of investment banks}

Our findings suggest that most (18 out of 21) convertible bond issuers rely heavily on their investment bank for a wide range of services associated with the bond offering. The most-often cited service is to help issuers with the appropriate timing of their offering (12 out of 21). Other important services include marketing of the offering, pricing, and assisting the firm with the actual security choice and the design of the offering. Three executives were more skeptical about the added value of investment banks. One of these executives stated that investment banks have an incentive to pitch convertible bonds as a viable security choice, since convertible bond deals involve high fees for relatively little work, as they can be quickly placed with hedge funds: "Well, I think any CFO is continually being chased and annoyed by the banks to issue convertibles, because convertibles are very easy for the banks to do. It is a relatively standard process. Compared to raising straight equity or straight debt it is quite good fees for not much effort." Finally, the managers stressed that the issuance of convertible bonds is ultimately the decision of the company rather than that of the investment banks. None of the interviewees ascribed the actual decision to issue convertibles to the investment banks.

\section{Conclusion}

We use in-depth interviews to study why companies issue convertible bonds. The main insight from our interviews is that managers use convertibles when they perceive these securities to be a cheaper form of financing than straight bonds and equity. Consistent with this result, a large-sample analysis of 15,805 security offerings shows that convertible issue decisions are influenced both by yield spreads between straight bonds and convertibles and the cost of equity, with the importance of these factors depending on the degree of perceived equity undervaluation. Firms with a strong perception that the market undervalues their equity at the 
time of issuance, which represent the majority of our interviewees, mainly use convertibles as an alternative to straight bonds when feature-adjusted yield differences with straight bonds are high. Firms with weaker concerns about equity undervaluation, in turn, mainly use convertibles as an alternative to equity. To our knowledge, our interview study is the first to document this 'lowest cost security' reasoning behind convertible bond issuance decisions. Our security choice analysis complements studies by Lewis et al. $(1999,2003)$ and Dutordoir and Van de Gucht (2009), who examine the impact of firm and macroeconomic characteristics on firms' choice between convertibles, straight bonds, and equity. Our analysis differs from theirs by considering feature-adjusted yield differences between straight bonds and convertibles, a determinant strongly suggested by our interviews as one of the key explanatory variables of firms' decisions to issue convertibles, and by showing that convertible issuance motives are conditional on perceived equity misvaluation by the market.

Importantly, while firms are strongly driven by cost differentials with straight bonds and equity at the time of issuance, they do not seem to be deluded about the true cost of convertibles. That is, firms seem well aware that convertibles may turn out to be a worse choice, ex post, compared with standard financing types.

In terms of academic theories, our interview findings highlight the central role of risk uncertainty (as in Brennan and Kraus, 1987; and Brennan and Schwartz, 1988) and of perceived equity undervaluation (as in Heaton, 2002; and Malmendier et al., 2011) in shaping corporate security choices. In contrast, we obtain little support for the backdoor equity rationale of Stein (1992), and virtually no support for the risk shifting model of Green (1984) and the sequential financing model of Mayers (1998).

Our results furthermore illustrate the strong impact of two factors largely ignored in security choice theories, i.e. investor demand and financial intermediaries. 
Synthesizing the responses on the open question and the theory-related questions, we conclude that convertibles tend to be used as a response to high perceived costs of issuing straight bonds and equity. This is conveniently captured in the following quote from one of the executives regarding the motives to issue convertibles: "When [to issue convertibles] is driven by capital needs of the company, and convertible bonds being evaluated and determined at the time to be the most cost effective financing vehicle available to the company within the overall capital structure that exists within the entity."

Our findings provide several new directions for research. Future studies may want to incorporate proxies for perceived stock misvaluation by the market at the time of issuance in tests of convertible bond announcement effects or post issue stock performance. In addition, our interview results imply that future security choice studies should control for the impact of investor demand and financial intermediaries by developing suitable empirical proxies.

An obvious problem with surveys and interviews is that it is difficult to go back to respondents at a later stage. With hindsight, we would have asked interviewees about their assessment of the probability of conversion at the time of issuance, as this information would have provided a cross-check of the interviewees' statements that their equity was undervalued by the market. Another question that could aid inference relates to the influence of investor demand on convertible bond design such as callability, conversion premium, and maturity. Finally, we would have asked managers up front if they would agree for their company to be named in the paper (we only asked this question at a later stage). Even though our work does have a strong element of replicability through its inclusion of a large-sample, easily executable security choice analysis, including all names of participating companies would have further enhanced its replicability. 


\section{References}

Alexander, G.J., Stover, R.D., Kuhnau, D.B., 1979. Market timing strategies in convertible debt financing. The Journal of Finance 34, 143-155.

Baker, M., 2009. Capital market driven corporate finance. Annual Review of Financial Economics 1, $1-41$.

Baker, M., Wurgler, J., 2002. Market timing and capital structure. The Journal of Finance 57, 1-32.

Baker, M., Wurgler, J., 2004. A catering theory of dividends. The Journal of Finance 59, 1125-1165.

Bayless, M., Chaplinsky, S., 1991. Expectations of security type and the information content of debt and equity offers. Journal of Financial Intermediation 1, 195-214.

Bradburn, N.M., Sudman, S., Wansink, B., 2004. Asking Questions: The Definitive Guide to Questionnaire Design. John Wiley \& Sons, San Francisco.

Brav, A., Graham, J.R., Harvey, C.R., Michaely, R., 2005. Payout policy in the $21^{\text {st }}$ century. Journal of Financial Economics 77, 483-527.

Brennan, M.J., Kraus, A., 1987. Efficient financing under asymmetric information. The Journal of Finance $42,1225-1243$.

Brennan, M.J., Schwartz, E.S., 1988. The case for convertibles. Journal of Applied Corporate Finance 1, 55-64.

Brown, S., Grundy, B., Lewis, C., Verwijmeren, P., 2012. Convertibles and hedge funds as distributors of equity exposure. The Review of Financial Studies 25, 3077-3112.

Chang, S.-C., Chen, S.-S., Liu, Y., 2004. Why firms use convertibles: A further test of the sequentialfinancing hypothesis. Journal of Banking and Finance 28, 1163-1183.

Choe, H., Masulis, R.W., Nanda, V., 1993. Common stock offerings across the business cycle: Theory and evidence. Journal of Empirical Finance 1, 3-31.

Choi, D., Getmansky, M., Henderson, B., Tookes, H., 2010. Convertible bond arbitrageurs as suppliers of capital. The Review of Financial Studies 23, 2492-2522.

DeAngelo, H., DeAngelo, L., Stulz, R., 2010. Seasoned Equity Offerings, Market Timing and the Corporate Lifecycle, Journal of Financial Economics 95, 275-295.

De Jong, A., Duca, E., Dutordoir, M., 2013. Do convertible bond issuers cater to investor demand? Financial Management 42, 41-78.

De Jong, A., Dutordoir, M., Verwijmeren, P., 2011. Why do convertible issuers simultaneously repurchase stock? An arbitrage-based explanation. Journal of Financial Economics 100, 113-129.

Dong, M., Hirschleifer, D., Teoh, S.H., Richardson, S., 2006. Does investor misvaluation drive the takeover market? The Journal of Finance 61, 725-762.

Dong, M., Loncarski, I., Ter Horst, J., Veld, C., 2012. What drives security issuance decisions: Market timing, pecking order, or both? Financial Management 41, 637-663.

Dorion, C., Francois, P., Grass, G., Jeanneret, A., 2014. Convertible debt and shareholder incentives. Journal of Corporate Finance 24, 38-56. 
Duca, E., Dutordoir, M., Veld, C., Verwijmeren, P., 2012. Why are convertible bond announcements associated with increasingly negative issuer stock returns? An arbitrage-based explanation. Journal of Banking and Finance 36, 2884-2899.

Dutordoir, M., Lewis, C., Seward, J. Veld, C., 2014. What we do and do not know about convertible bond financing. Journal of Corporate Finance 24, 3-20.

Dutordoir, M., Van de Gucht, L., 2007. Are there windows of opportunity for convertible debt issuers? Evidence for Western Europe. Journal of Banking and Finance 31, 2828-2846.

Dutordoir, M., Van de Gucht, L., 2009. Why do Western European firms issue convertibles instead of straight debt or equity? European Financial Management 15, 563-583.

Eisenhardt, K.M., 1989. Building theories from case study research. Academy of Management Review $14,532-550$.

Fang, L.H., 2005. Investment bank reputation and the price and quality of underwriting services. The Journal of Finance 60, 2729-2761.

Faulkender, M., Petersen, M.A., 2006. Does the source of capital affect capital structure? The Review of Financial Studies 19, 45-79.

Gillham, B., 2008. Research Interviewing: The Range of Techniques. Open University Press, Mc-Graw Hill, Berkshire, England.

Gomes, A., Phillips, G., 2012. Why do public firms issue private and public securities? Journal of Financial Intermediation 2012, 619-658.

Graham, J.R., 1999. Quarter 2, 1999 FEI Survey. http://www.duke.edu/ jgraham.

Graham, J.R., Harvey, C.R., 2001. The theory and practice of corporate finance: Evidence from the field. Journal of Financial Economics 61, 187-243.

Graham, J.R., Harvey, C.R., Rajgopal, S., 2005. The economic implications of corporate financial reporting. Journal of Accounting and Economics 40, 3-73.

Green, R., 1984. Investment incentives, debt, and warrants. Journal of Financial Economics 13, 115-136.

Heaton, J.B., 2002. Managerial optimism and corporate finance. Financial Management 31, 33-45.

Henderson, B.J., Tookes, H., 2012. Do investment banks' relationships with investors impact pricing? The case of convertible bond issues. Management Science 58, 2272-2291.

Hillier, D., Ross, S., Westerfield, R., Jaffe, J., Jordan, B., 2013. Corporate Finance. $2^{\text {nd }}$ European edition.

Jenter, D., 2005, Market timing and managerial portfolio decisions. The Journal of Finance 60, 19031949.

Jung, K., Kim, Y., Stulz, R., 1996. Timing, investment opportunities, managerial discretion, and the security issue design. Journal of Financial Economics 42, 159-185.

Kim, Y.O., 1990. Informative conversion ratios: A signalling approach. Journal of Financial and Quantitative Analysis 25, 229-243.

Korajczyk, R.A., Levy, A., 2003. Capital structure choice: Macroeconomic conditions and financial constraints. Journal of Financial Economics 68, 75-109. 
Kvale, S., Brinkmann, S., 2009. Interviews: Learning the Craft of Qualitative Research Interviewing. Sage Publications, California.

Leary, M.T., 2009. Bank loan supply, lender choice and corporate capital structures. The Journal of Finance 64, 1143-1185.

Lee, I., Loughran, T., 1998. Performance following convertible bond issuance. Journal of Corporate Finance 4, 185-207.

Lemmon, M.L., Roberts, M., 2010. The response of corporate financing and investment to changes in the supply of credit. Journal of Financial and Quantitative Analysis 45, 555-587.

Lewis, C.M., Rogalski, R.J., Seward, J.K., 1998. Agency problems, information asymmetries, and convertible debt security design. Journal of Financial Intermediation 7, 32-59.

Lewis, C.M., Rogalski, R.J., Seward, J.K., 1999. Is convertible debt a substitute for straight debt or for common equity? Financial Management 28, 5-27.

Lewis, C.M., Rogalski, R.J., Seward, J.K., 2001. The long-run performance of firms that issue convertible debt: An empirical analysis of operating characteristics and analyst forecasts. Journal of Corporate Finance 7, 447-474.

Lewis, C.M., Rogalski, R.J., Seward, J.K., 2003. Industry conditions, growth opportunities and market reactions to convertible debt financing decisions. Journal of Banking and Finance 27, 153-181.

Lintner, J., 1956. Distribution of incomes of corporations among dividends, retained earnings, and taxes. The American Economic Review 46, 97-113.

Loncarski, I., Ter Horst, J., Veld, C., 2009. The rise and demise of the convertible arbitrage strategy. Financial Analysts Journal 65, 35-50.

Malmendier, U., Tate, G.A., Yan, J., 2011. Overconfidence and early-life experience: The effect of managerial traits on corporate financial policies. The Journal of Finance 66, 1687-1733.

Mann, S.V., Moore, W.T., Ramanlal, P., 1999. Timing of convertible debt issues. Journal of Business Research 45, 101-105.

Mayers, D., 1998. Why firms issue convertible bonds: The matching of financial and real investment options. Journal of Financial Economics 47, 83-102.

McCracken, G., 1988. The Long Interview. Thousand Oaks, CA: Sage.

Myers, S.C., Majluf, N.S., 1984. Corporate financing and investment decisions when firms have information that investors do not have. Journal of Financial Economics 13, 187-221.

Reisel, N., 2014. On the value of restrictive covenants: Empirical investigation of public bond issues. Journal of Corporate Finance 27, 251-268.

Stein, J.C., 1992. Convertible bonds as backdoor equity financing. Journal of Financial Economics 32. 321. 


\section{Table 1: Sample description}

Description: Panel A of this table reports the job titles of the interviewees and the issuance year of the convertibles in the data set. For companies that issued two convertibles over the research period, we mention the issuance year of the last offering to avoid potential identification of the firm. Panel B includes the industry dispersion by the two-digit SIC code.

Interpretation: The convertibles were issued in Australia (AUS), Canada (CAN), the United Kingdom (UK), and the United States (US) between 2005 and 2011. Eight companies agreed to be named.

\begin{tabular}{|c|c|c|c|}
\hline $\begin{array}{l}\text { Company } \\
\text { code }\end{array}$ & $\begin{array}{l}\text { Company Name (If consented to } \\
\text { be named) }\end{array}$ & Interviewee job title ${ }^{a}$ & Issuance year \\
\hline AUS1 & \multirow[t]{3}{*}{ World Reach } & & 2008 \\
\hline AUS2 & & $\mathrm{CFO}$ & 2007 \\
\hline AUS3 & & $\mathrm{CFO}$ & 2005 \\
\hline CAN1 & \multirow[t]{3}{*}{ Extendicare } & & 2008 \\
\hline CAN2 & & Vice President Finance & 2007 \\
\hline CAN3 & & $\mathrm{CFO}$ & 2007 \\
\hline CAN4 & \multirow[t]{3}{*}{ FirstService } & & 2009 \\
\hline CAN5 & & $\mathrm{CFO}$ & 2008 \\
\hline UK1 & & $\begin{array}{l}\text { 1) CFO and 2) Director of } \\
\text { Corporate Finance }\end{array}$ & 2007 \\
\hline UK2 & \multirow[t]{2}{*}{ WPP } & & 2009 \\
\hline UK3 & & Treasurer & 2009 \\
\hline UK4 & \multirow[t]{2}{*}{ Ophir Energy PLC } & & 2010 \\
\hline UK5 & & Treasurer & 2009 \\
\hline UK6 & Aberdeen Asset Management & Finance Director & 2009 \\
\hline US1 & \multirow[t]{5}{*}{ Exterran Energy Solutions, L.P. } & & 2009 \\
\hline US2 & & Treasurer & 2010 \\
\hline US3 & & $\mathrm{CFO}$ & 2006 \\
\hline US4 & & $\mathrm{CFO}$ & 2011 \\
\hline US5 & & $\mathrm{CFO}$ & 2010 \\
\hline US6 & \multirow[t]{2}{*}{ Hercules Offshore Inc. } & & 2008 \\
\hline US7 & & $\mathrm{CFO}$ & 2007 \\
\hline
\end{tabular}

a When the issuing company is named, we do not show the interviewee's position for anonymity reasons. 
Table 2: Descriptive statistics for sample firms and convertibles

Description: This table reports descriptive firm- (convertible)-specific characteristics for the 21 sample companies. Company-specific data are obtained from Datastream and converted to U.S. dollars using the exchange rate prevailing one week before the issuance date. All accounting variables are measured at the fiscal year-end before the issuance date. Book-to-market ratio is book value of common equity divided by the market value of equity. Volatility is daily stock return volatility over the 60 days prior to the issue month. Return on assets is net income divided by total assets. Leverage is total debt divided by total assets. Cash is cash and marketable securities scaled by total assets. Age is firm age in years measured from the first date of Datastream coverage to the issue date. Issue characteristics are obtained from Thomson ONE Banker. Conversion premium is the premium of conversion price relative to the stock price prevailing one day prior to the convertible bond issuance date. Investment grade is an indicator that equals one if the convertible has an investment grade credit rating and zero otherwise. CAR is the three-day cumulative abnormal return around the announcement of the issue estimated by a market model. The other issuer and issue characteristics are self-explanatory.

Interpretation: Most issuers in our interview sample tend to be not very profitable, small, and have a low bookto-market ratio. They typically do not have an investment grade rating, and have a high conversion premium relative to the full sample median of $25 \%$ of U.S. convertibles during 1980-2014.

\begin{tabular}{lccc}
\hline Company-specific information & Mean & Median & Standard deviation \\
\hline Book-to-market ratio & 0.65 & 0.32 & 0.60 \\
Volatility (\%) & 3.46 & 2.41 & 3.12 \\
Return on assets & -0.22 & 0.00 & 0.70 \\
Leverage & 0.30 & 0.31 & 0.23 \\
Cash & 0.26 & 0.15 & 0.27 \\
Age & 14.51 & 11.67 & 14.07 \\
Total assets (\$M) & 8,564 & 2,135 & 15,781 \\
& & & \\
\hline Convertible-specific information & Mean & Median & Standard deviation \\
\hline Coupon (\%) & 5.05 & 4.25 & 2.31 \\
Conversion premium (\%) & 30.25 & 29.04 & 9.45 \\
Maturity (years) & 7.29 & 5.00 & 6.30 \\
Proceeds (\$M) & 279 & 123 & 397 \\
Proceeds/Total assets & 0.23 & 0.09 & 0.31 \\
Investment grade & 0.29 & 0.00 & 0.46 \\
CAR (\%) & -2.51 & -2.61 & 5.13 \\
\hline
\end{tabular}




\section{Table 3. Detailed convertible debt issuance motivations provided by the interviewees}

Description: This table reports the answers to the question that we posed to managers to describe in their own words why they issued convertible bonds. Based on their answers, we divide them into the following types: (1) 'Coupon' issuers for which straight debt, in terms of coupon rate, was too expensive; (2) 'Covenant' issuers for which straight debt was too costly in terms of restrictive covenants; (3) 'Constrained' issuers for which straight debt was not accessible, and (4) a 'Repurchase' issuer that wanted to issue convertibles to help finance an equity repurchase.

Interpretation: Firms prefer convertibles to straight debt because of the prohibitively high coupon payments on straight debt. This argument was particularly relevant for the Coupon firms, but was also relevant for other firms. Covenant firms preferred convertibles mainly to avoid restrictive covenants, but also to reduce coupon payments. Constrained firms did not have the capacity to issue straight debt. Firms prefer convertibles to equity because they perceive their stock to be undervalued by the market, or because they have concerns about diluting shareholder value. All types of issuers attempted to issue the cheapest security available, although most issuers in the interview sample considered convertibles mainly as an alternative to straight debt. Investor demand for convertibles was also an often cited argument.

\begin{tabular}{|c|c|c|c|}
\hline $\begin{array}{l}\text { Company } \\
\text { number } \\
\text { (Type) }\end{array}$ & $\begin{array}{l}\text { Why was convertible preferred to straight } \\
\text { debt? }\end{array}$ & Why was convertible preferred to equity? & $\begin{array}{l}\text { Other insights (e.g., equity valuation and } \\
\text { investor demand) }\end{array}$ \\
\hline $\begin{array}{l}\text { Firm } 1 \\
\text { (Coupon) } \\
\text { Extendicare } \\
\text { (CAN1) }\end{array}$ & $\begin{array}{l}\text { 1. Convertible was preferred to straight } \\
\text { debt because of the lower coupon. }\end{array}$ & $\begin{array}{l}\text { 2. We prefer debt to equity financing if } \\
\text { there is sufficient debt capacity } \\
\text { available. But the leverage level had } \\
\text { recently gone up, and we believe } \\
\text { convertibles should not take up more } \\
\text { than } 20 \% \text { of the balance sheet. So, this } \\
\text { convertible was done as a "combo offer" } \\
\text { along with an equity issue (in terms of } \\
\text { dollar amount: the issue was } 2 / 3^{\text {rd }} \\
\left.\text { convertible and } 1 / 3^{\text {rd }}\right) \text {. }^{\text {a }} \\
\text { Share price had recently gone down, and } \\
\text { analysts did not think equity offering } \\
\text { would be a good decision. }\end{array}$ & $\begin{array}{l}\text { 4. If share price were even lower, we } \\
\text { would have used more convertible } \\
\text { bond financing and reduced the total } \\
\text { issuance proceeds. }\end{array}$ \\
\hline $\begin{array}{l}\text { Firm } 2 \\
\text { (Coupon) }\end{array}$ & $\begin{array}{l}\text { 1. Bank debt market was closed at the time. } \\
\text { Straight bond coupon was much higher } \\
\text { than the yield on convertible (about } 10 \% \\
\text { compared with } 4 \% \text { ), and the differential } \\
\text { was at an extreme level. }\end{array}$ & $\begin{array}{l}\text { 2. We ruled out equity previously. } \\
\text { Convertible would have limited effects } \\
\text { of equity dilution compared to an equity } \\
\text { offer. }\end{array}$ & $\begin{array}{l}\text { 3. We had just issued a second positive } \\
\text { trading statement in a two-month } \\
\text { period. Our share price had come off its } \\
\text { low and almost tripled, which was } \\
\text { critical for issuing a meaningful } \\
\text { amount of convertible capital. } \\
\text { 4. Convertible market was hot; there was } \\
\text { strong demand not only from hedge } \\
\text { funds but also from long-only }\end{array}$ \\
\hline
\end{tabular}




\begin{tabular}{|c|c|c|c|c|}
\hline & & & & $\begin{array}{l}\text { convertible bond funds. The stock } \\
\text { return volatility was high, making the } \\
\text { conversion premium more attractive. }\end{array}$ \\
\hline $\begin{array}{l}\text { Firm } 3 \\
\text { (Coupon) }\end{array}$ & $\begin{array}{l}\text { 1. Low coupon on the convertible was } \\
\text { attractive: } 2-3 \% \text { for convertible versus } \\
5 \% \text { for straight debt. }\end{array}$ & $\begin{array}{l}\text { 2. We also issued debt and equity around } \\
\text { the same time. We decided to use all } \\
\text { these instruments to keep our balance } \\
\text { sheet in equilibrium, in terms of the debt } \\
\text { service coverage ratio. }\end{array}$ & 4. & $\begin{array}{l}\text { The main reason for issuing } \\
\text { convertible was pricing: conversion } \\
\text { premium was a historical high }(30 \%) \\
\text { in the industry, while it used to be } \\
\text { below } 20 \% \text {. } \\
\text { Recent stock price rally encouraged us } \\
\text { to issue convertible. Otherwise we } \\
\text { would have hesitated. }\end{array}$ \\
\hline $\begin{array}{l}\text { Firm } 4 \\
\text { (Coupon) }\end{array}$ & $\begin{array}{l}\text { 1. Straight debt was too expensive because } \\
\text { we did not have a credit rating. We were } \\
\text { wary to acquire such rating because it } \\
\text { was likely to be very poor. Private debt } \\
\text { would be covenant-heavy and } \\
\text { expensive. }\end{array}$ & $\begin{array}{l}\text { 2. Equity was undervalued and we wanted } \\
\text { to avoid equity dilution. } \\
\text { 3. We used a call spread overlay to reduce } \\
\text { the potential equity dilution by } \\
\text { increasing the effective conversion } \\
\text { premium. }\end{array}$ & 5. & $\begin{array}{l}\text { If the stock was trading significantly } \\
\text { higher, we would have given more } \\
\text { serious consideration to an equity } \\
\text { offer. } \\
\text { The convertible bond market was hot } \\
\text { at that time. }\end{array}$ \\
\hline $\begin{array}{l}\text { Firm } 5 \\
\text { (Coupon) } \\
\text { Aberdeen } \\
\text { Asset } \\
\text { Management } \\
\text { (UK6) }\end{array}$ & $\begin{array}{l}\text { 1. The banking market had become very } \\
\text { difficult. It was hard to obtain financing } \\
\text { even from relationship banks. }\end{array}$ & $\begin{array}{l}\text { 2. We did not consider equity because of } \\
\text { equity dilution and undervaluation } \\
\text { concerns. } \\
\text { 3. We were pretty confident that our future } \\
\text { business growth would enable } \\
\text { conversion of its convertible debt rather } \\
\text { than being forced to repay it after five } \\
\text { years. }\end{array}$ & 4 & $\begin{array}{l}\text { It is always more efficient to finance at } \\
\text { least partially by debt. }\end{array}$ \\
\hline $\begin{array}{l}\text { Firm } 6 \\
\text { (Coupon) }\end{array}$ & $\begin{array}{l}\text { 1. We chose convertible bond over straight } \\
\text { debt because the cost of straight debt } \\
\text { would be much higher. }\end{array}$ & $\begin{array}{l}\text { 2. We did not want to issue equity out of } \\
\text { fear of dilution. Moreover, our stock } \\
\text { traded around book tangible value and } \\
\text { was believed to be underpriced. } \\
\text { 3. We used a call spread overlay in } \\
\text { combination with the convertible offer } \\
\text { to reduce the potential equity dilution. }\end{array}$ & 4. & $\begin{array}{l}\text { Economic cost of the convertible and } \\
\text { call spread transaction was } \\
\text { significantly cheaper than straight debt } \\
\text { coupon. }\end{array}$ \\
\hline $\begin{array}{l}\text { Firm } 7 \\
\text { (Coupon) } \\
\text { WPP (UK2) }\end{array}$ & $\begin{array}{l}\text { 1. Cost of straight bonds was too high. The } \\
\text { bond yield had reached } 11 \% \text { ("too } \\
\text { painful to consider at its simplest") and }\end{array}$ & $\begin{array}{l}\text { 3. We believed that stock was underpriced } \\
\text { and therefore did not want to issue }\end{array}$ & 4. & $\begin{array}{l}\text { The convertible market opened. The } \\
\text { issue was heavily over-subscribed }\end{array}$ \\
\hline
\end{tabular}




\begin{tabular}{|c|c|c|c|}
\hline & $\begin{array}{l}\text { even that yield could not guarantee bond } \\
\text { sale. } \\
\text { 2. We wanted to issue convertibles to } \\
\text { signal to the market that we still had } \\
\text { financing capabilities, thereby reducing } \\
\text { the future cost of debt. }\end{array}$ & $\begin{array}{l}\text { equity. We had told our shareholders that } \\
\text { we would not issue equity. }\end{array}$ & $\begin{array}{l}\text { which allowed us to achieve a high } \\
\text { conversion premium. }\end{array}$ \\
\hline $\begin{array}{l}\text { Firm } 8 \\
\text { (Coupon) }\end{array}$ & $\begin{array}{l}\text { 1. Convertible was cheaper and had a much } \\
\text { lower coupon than straight debt ( } 8 \% \text { for } \\
\text { convertible versus about } 15 \% \text { for } \\
\text { straight debt). }\end{array}$ & $\begin{array}{l}\text { 2. We did not consider issuing straight } \\
\text { equity because of dilution and } \\
\text { undervaluation concerns. } \\
\text { 3. Convertible represents delayed equity, } \\
\text { and the lower coupon more than } \\
\text { compensates for any dilution to equity } \\
\text { holders. }\end{array}$ & $\begin{array}{l}\text { 4. If equity valuation would have been } \\
\text { lower, we might have considered } \\
\text { straight debt. } \\
\text { 5. Conversely, if we believed there was } \\
\text { not much potential for the stock price } \\
\text { to go up, then we would have issued } \\
\text { equity because the conversion price } \\
\text { would never be reached. } \\
\text { 6. The convertible market was getting hot } \\
\text { and convertible debt was becoming a } \\
\text { fairly common instrument. Companies } \\
\text { of similar sizes were using them. }\end{array}$ \\
\hline $\begin{array}{l}\text { Firm } 9 \\
\text { (Coupon) }\end{array}$ & $\begin{array}{l}\text { 1. The first priority would be to issue } \\
\text { straight debt. However, we had just } \\
\text { issued a large amount of straight bonds. } \\
\text { The bank debt market was dysfunctional } \\
\text { at the time. Straight bond yield was more } \\
\text { than double the yield on convertible, and } \\
\text { the yield differential between straight } \\
\text { debt and convertible was at an extreme } \\
\text { level. }\end{array}$ & $\begin{array}{l}\text { Equity was not issued because we did } \\
\text { not want the dilution. Convertible would } \\
\text { have very limited effect in terms of } \\
\text { dilution in comparison to an equity issue. } \\
\text { 3. The convertible issue was also intended } \\
\text { to eliminate speculation about a rights } \\
\text { issue of equity. }\end{array}$ & $\begin{array}{l}\text { 4. Share price had rallied more than } 50 \% \\
\text { recently and the rally coincided with } \\
\text { very attractive market conditions. But } \\
\text { our stock price was not the primary } \\
\text { reason for the convertible decision. An } \\
\text { equity issue would have involved more } \\
\text { of a play on stock price). } \\
\text { 5. We had been monitoring the } \\
\text { convertible market for about } 18 \\
\text { months. It was a good moment to enter } \\
\text { the convertible market. }\end{array}$ \\
\hline $\begin{array}{l}\text { Firm } 10 \\
\text { (Coupon) } \\
\text { Ophir Energy } \\
\text { (UK4) }\end{array}$ & $\begin{array}{l}\text { 1. Debt capacity was close to full }(20 \% \text { of } \\
\text { total assets was in straight asset-backed } \\
\text { debt). Any incremental subordinated } \\
\text { debt would be quite expensive. We did } \\
\text { not want to "over-gear" the business. }\end{array}$ & $\begin{array}{l}\text { 2. Equity was not issued because we did } \\
\text { not want the dilution. We believed } \\
\text { shares to be underpriced because growth } \\
\text { opportunities had not been realized or } \\
\text { reflected in the share price. }\end{array}$ & $\begin{array}{l}\text { 3. Timing was right, and the price and } \\
\text { coupon rates were good. }\end{array}$ \\
\hline
\end{tabular}




\begin{tabular}{|c|c|c|c|}
\hline $\begin{array}{l}\text { Firm 11 } \\
\text { (Coupon) } \\
\text { Hercules } \\
\text { Offshore } \\
\text { (US6) }\end{array}$ & $\begin{array}{l}\text { 1. Our stock was "well valued". It was } \\
\text { trading near all-time highs. If the } \\
\text { convertible debt was converted into } \\
\text { shares, the conversion price would be so } \\
\text { high that equity dilution would be a } \\
\text { "good problem to have". If the } \\
\text { convertible debt would not be } \\
\text { converted, the coupon would be lower } \\
\text { compared with straight debt. }\end{array}$ & $\begin{array}{l}\text { 2. Did not issue equity because of dilution } \\
\text { concerns: we preferred to issue at } \\
\text { conversion price rather than the current } \\
\text { price. Did not use debt because } \\
\text { convertible debt had lower coupon rate. }\end{array}$ & $\begin{array}{l}\text { 3. If the stock was trading significantly } \\
\text { lower, then we would not have issued } \\
\text { convertibles, because if the stock price } \\
\text { would go up, the effective price to } \\
\text { issues shares would still be too low; } \\
\text { and if price would go down, the firm } \\
\text { would still be left with debt to pay. } \\
\text { 4he convertible market was good and } \\
\text { many recent issues from other firms } \\
\text { were oversubscribed. }\end{array}$ \\
\hline $\begin{array}{l}\text { Firm 12 } \\
\text { (Coupon) } \\
\text { Exterran } \\
\text { Energy } \\
\text { Solutions, L.P. } \\
\text { (US1) }\end{array}$ & $\begin{array}{l}\text { Straight debt was too costly compared to } \\
\text { convertible debt. The yield on straight } \\
\text { debt was nearly three times the yield on } \\
\text { convertible. }\end{array}$ & $\begin{array}{l}\text { 2. Equity was not considered because of } \\
\text { share dilution. I believe that equity is the } \\
\text { most expensive form of financing } \\
\text { because of dilution, and that every } \\
\text { company prefers debt to equity financing } \\
\text { if possible. } \\
\text { 3. Stock price was certainly not } \\
\text { overvalued, and perhaps undervalued. } \\
\text { 4. We used a call spread overlay in } \\
\text { combination with the convertible offer to } \\
\text { reduce the potential share dilution by } \\
\text { increasing the effective conversion } \\
\text { premium. }\end{array}$ & $\begin{array}{l}\text { 5. The convertible market was fairly } \\
\text { strong. }\end{array}$ \\
\hline $\begin{array}{l}\text { Firm } 13 \\
\text { (Coupon) }\end{array}$ & $\begin{array}{l}\text { We did not use straight debt because the } \\
\text { company was still at an early growth } \\
\text { stage and convertibles had a much lower } \\
\text { coupon }(5 \% \text { for convertibles compared } \\
\text { to about } 30 \% \text { for straight bonds). }\end{array}$ & $\begin{array}{l}\text { 2. We did not issue equity because of } \\
\text { dilution concerns. } \\
\text { 3. We thought that the stock price could } \\
\text { increase dramatically. We used call } \\
\text { spread overlays to protect ourselves } \\
\text { against the adverse effects of such stock } \\
\text { price increases. }\end{array}$ & $\begin{array}{l}\text { 4. We did not wait purposefully until the } \\
\text { convertible bond market was hot. We } \\
\text { decided which security type to issue } \\
\text { based on the market condition at the } \\
\text { time of financing. }\end{array}$ \\
\hline $\begin{array}{l}\text { Firm } 14 \\
\text { (Covenant) }\end{array}$ & $\begin{array}{l}\text { The primary reason is that convertible } \\
\text { debt avoided restrictive covenants that } \\
\text { would have disallowed the use of funds } \\
\text { for actions such as acquisitions. }\end{array}$ & $\begin{array}{l}\text { 4. Did not consider equity issue because } \\
\text { shareholders (especially the four or five } \\
\text { largest shareholders) did not want that } \\
\text { level of dilution. Shareholders were } \\
\text { "perfectly happy with the convertible". }\end{array}$ & $\begin{array}{l}\text { 5. The convertible market was getting } \\
\text { hot. There was a window of } \\
\text { opportunity for very attractive terms } \\
\text { and low interest coupons. Hurdle rates } \\
\text { (i.e., conversion rates) could be very } \\
\text { high. }\end{array}$ \\
\hline
\end{tabular}




\begin{tabular}{|c|c|c|c|}
\hline & $\begin{array}{l}\text { Recent share price increase }(20-30 \%) \\
\text { made convertible less costly compared } \\
\text { to subordinated bank loans. } \\
\text { 3. The leverage level was not aggressive, } \\
\text { and shareholders would prefer to use } \\
\text { debt to equity issuance. }\end{array}$ & & \\
\hline $\begin{array}{l}\text { Firm } 15 \\
\text { (Covenant) } \\
\text { Firstservice } \\
\text { (CAN4) }\end{array}$ & $\begin{array}{l}\text { 1. We considered straight debt but did not } \\
\text { choose it because of the covenants and } \\
\text { the increase in the leverage. }\end{array}$ & $\begin{array}{l}\text { 2. Stock price had doubled, but we believe } \\
\text { our stock was still undervalued. Equity } \\
\text { issue would be too dilutive; issuing at the } \\
\text { conversion price would be more } \\
\text { reasonable. }\end{array}$ & $\begin{array}{l}\text { The conversion premium was } \\
\text { unusually high: } 40 \% \text { compared to the } \\
\text { norm of } 10-20 \% \text {. } \\
\text { 4. The opportunity to take on convertible } \\
\text { debt became available and we seized it. }\end{array}$ \\
\hline $\begin{array}{l}\text { Firm } 16 \\
\text { (Covenant) }\end{array}$ & $\begin{array}{l}\text { 1. There was room in the debt structure, but } \\
\text { we did not consider straight debt because } \\
\text { of the covenants. } \\
\text { 2. Convertible was considered as a safer } \\
\text { form of debt which can be settled by } \\
\text { shares. }\end{array}$ & $\begin{array}{l}\text { 3. We had recently issued large amounts of } \\
\text { equity. Stock price was not at a good } \\
\text { level for an equity issue, in the sense that } \\
\text { the stock price had gone up substantially } \\
\text { and shareholders would not believe a big } \\
\text { potential to gain. }\end{array}$ & $\begin{array}{l}\text { 4. The convertible market had become } \\
\text { more active. }\end{array}$ \\
\hline $\begin{array}{l}\text { Firm } 17 \\
\text { (Constrained) }\end{array}$ & $\begin{array}{l}\text { 1. Bank debt market was closed at the time. } \\
\text { Banks believed our project was risky and } \\
\text { we would need to issue an equal amount } \\
\text { of equity to have the ability to service } \\
\text { any new debt. } \\
\text { 2. Another reason for not issuing straight } \\
\text { debt was that the covenant structure } \\
\text { proposed by the banks was fairly } \\
\text { prohibitive. }\end{array}$ & $\begin{array}{l}\text { 3. Equity was not considered because our } \\
\text { stock was underpriced (the market was } \\
\text { skeptical about the value of current } \\
\text { assets and future projects). Convertible } \\
\text { bonds would have very limited effect of } \\
\text { dilution in comparison to an equity } \\
\text { issue: they would convert to equity at a } \\
\text { premium while new equity would be } \\
\text { issued at a discount. }\end{array}$ & $\begin{array}{l}\text { 4. As part of the convertible issue we } \\
\text { negotiated a carve-out to allow us to } \\
\text { raise future secured debt if needed. }\end{array}$ \\
\hline $\begin{array}{l}\text { Firm } 18 \\
\text { (Constrained) } \\
\text { Worldreach } \\
\text { (AUS1) }\end{array}$ & $\begin{array}{l}\text { 1. Bank debt was not extendable. We had } \\
\text { no access to straight bonds. }\end{array}$ & $\begin{array}{l}\text { 2. Equity was not considered because } \\
\text { shareholders (including a large } \\
\text { shareholder who was going to provide } \\
\text { substantial funds) wanted to have the } \\
\text { option of converting to equity rather than } \\
\text { just straight equity. }\end{array}$ & $\begin{array}{l}\text { 3. Stock was fairly priced even though we } \\
\text { were in financial distress. Conversion } \\
\text { premium was set a reasonable level, so } \\
\text { if conversion had happened, both } \\
\text { existing shareholders and convertible } \\
\text { note holders would have been quite } \\
\text { happy. }\end{array}$ \\
\hline
\end{tabular}




\begin{tabular}{|c|c|c|c|}
\hline $\begin{array}{l}\text { Firm } 19 \\
\text { (Constrained) }\end{array}$ & $\begin{array}{l}\text { 1. Straight debt was not possible because } \\
\text { we did not have positive revenues. }\end{array}$ & $\begin{array}{l}\text { 2. We were ready to list our stock on the } \\
\text { European stock market where our } \\
\text { investor base should be (as our } \\
\text { technology resonates better with } \\
\text { European investors). Our shareholders } \\
\text { were not supportive of us issuing new } \\
\text { equity in our home market. }\end{array}$ & $\begin{array}{l}\text { 3. We were looking for a bridge } \\
\text { financing. The financing was a life- } \\
\text { and-death question for the firm's } \\
\text { existence. We believed that if the } \\
\text { listing in Europe could happen, that } \\
\text { would lift a big doubt about financing } \\
\text { and our share price in our home market } \\
\text { would rally. } \\
\text { Even though unhappy with the stock } \\
\text { price, we believed that the stock price } \\
\text { was a fair reflection of the financial } \\
\text { stress at the time. }\end{array}$ \\
\hline $\begin{array}{l}\text { Firm } 20 \\
\text { (Constrained) }\end{array}$ & $\begin{array}{l}\text { 1. Bank debt was not accessible, and we } \\
\text { had no access to straight debt because we } \\
\text { had not established steady cash flows } \\
\text { with positive earnings. }\end{array}$ & $\begin{array}{l}\text { 2. We did not consider equity because the } \\
\text { stock was down and underpriced. A } \\
\text { convertible could take advantage of } \\
\text { perhaps a better stock price in the future. }\end{array}$ & $\begin{array}{l}\text { 3. Our shareholders, including two large } \\
\text { shareholders who were going to } \\
\text { provide substantial funds, preferred } \\
\text { convertible bonds. }\end{array}$ \\
\hline $\begin{array}{l}\text { Firm } 21 \\
\text { (Repurchase) }\end{array}$ & $\begin{array}{l}\text { 1. We used convertible debt instead of } \\
\text { straight debt mainly to reduce the } \\
\text { downside risk. If stock price would go } \\
\text { down, convertible would be less costly } \\
\text { because its coupon rate is lower than the } \\
\text { coupon of a straight bond. Straight debt } \\
\text { would turn out to be a good instrument } \\
\text { only if the stock price would go up. }\end{array}$ & $\begin{array}{l}\text { 2. Our stock was undervalued. We wanted } \\
\text { to issue a debt instrument to buy back } \\
\text { shares, instead of using our own cash } \\
\text { stored overseas, to save tax. } \\
\text { 3. We used call spread overlays to protect } \\
\text { us from equity dilution. }\end{array}$ & $\begin{array}{l}\text { 4. We also used an interest rate swap to } \\
\text { convert the fixed coupon into floating } \\
\text { coupon payments, in order to match the } \\
\text { balance sheet cash that was earning a } \\
\text { floating rate. }\end{array}$ \\
\hline
\end{tabular}

${ }^{a}$ Firm 1 is the only firm in our sample that co-issued convertibles together with another type of financing (equity issue).

${ }^{\mathrm{b}}$ Even though Firm 4 said it liked to have less covenants, we labelled the firm as a coupon issuer, because the interviewee did not list covenants as a primary motive for choosing convertibles in answering the first open question.

${ }^{c}$ Ophir Energy (called Salamander Energy at the time of the interview) was quite close to the constrained firm type, except that it could still issue straight debt (with a high coupon rate) if it wanted. The difference with the constrained firms is that they indicated that straight debt was not accessible.

${ }^{\mathrm{d}}$ This firm was viewed as excessively risky by the market at the time of issuance, which explains the $30 \%$ coupon on its straight debt (that could be undervalued by the market). The $25 \%$ reduction of coupon in its convertible likely reflects the very high price of the conversion option. The market may have considered that the upside of equity could justify the conversion option. 
Table 4. Summary of interview findings

Description: This table summarizes the main findings of a total of 21 interviews involving 23 convertible issues by firms in Australia, Canada, the U.K., and the U.S.

Interpretation: The interviewees mainly use convertibles as an alternative for costly straight bonds after having ruled out equity first. The risk uncertainty rationale of Brennan and Kraus (1987) and Brennan and Schwartz (1988) receives substantial support. We find little or no support for the risk shifting theory of Green (1984), the sequential financing model of Mayers (1998), and the backdoor equity rationale of Stein (1992). Investment bank advice is important in the decision to issue convertible bonds and their advice on the demand side of the market is deemed important. Hedge funds are heavily involved as buyers of the convertible bonds.

Panel A. Spontaneously-cited issuance motives

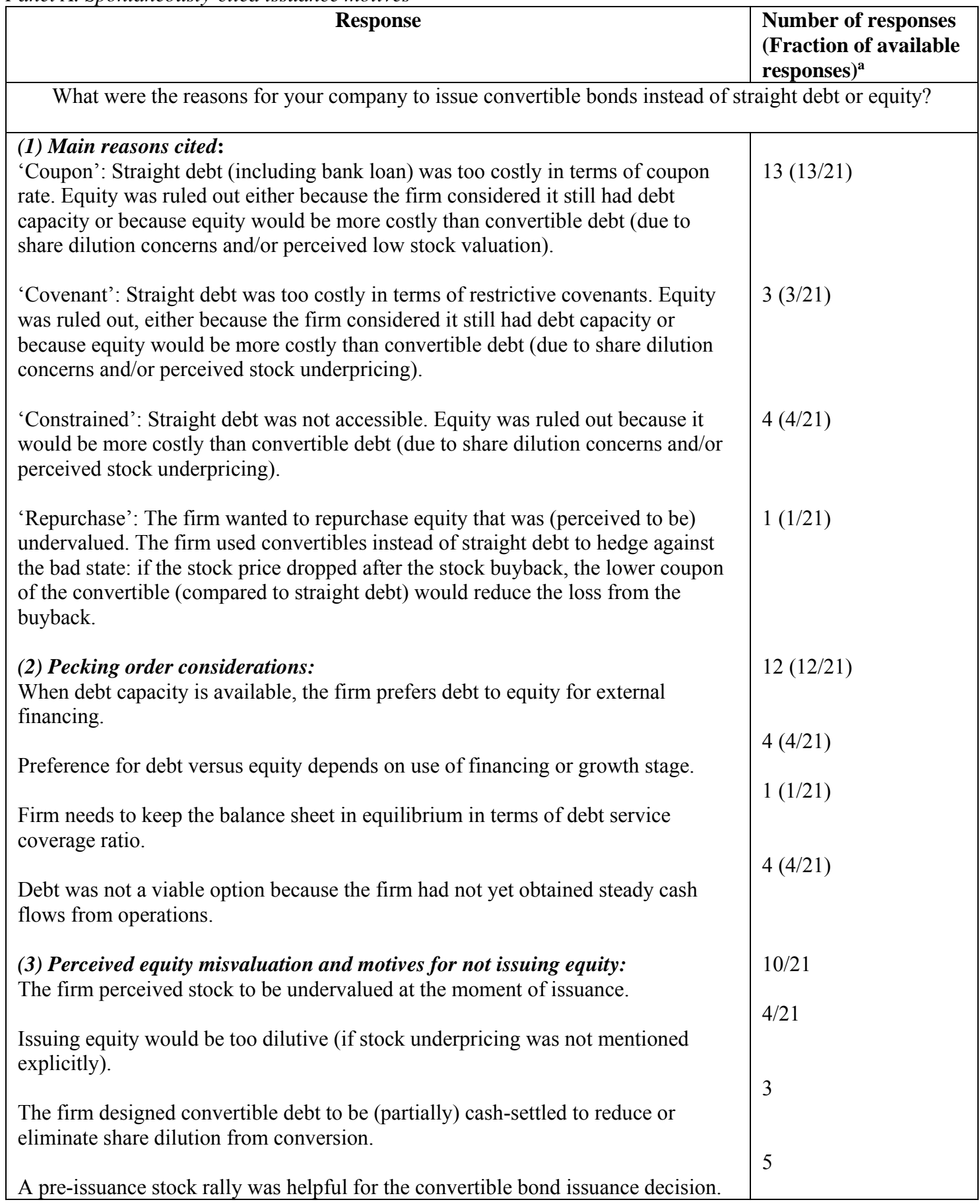




\begin{tabular}{|l|l|}
\hline $\begin{array}{l}\text { A high stock price at issuance and/or a high conversion premium were helpful for } \\
\text { the convertible bond issuance decision. }\end{array}$ & $7^{\mathrm{b}}$ \\
$\begin{array}{l}\text { If the stock price had been lower, the firm would have used (a larger fraction of) } \\
\text { straight debt financing instead of convertible bond financing, or (a larger fraction } \\
\text { of) convertible bond financing instead of equity. }\end{array}$ & $3^{\mathrm{b}}$ \\
$\begin{array}{l}\text { If the stock price had been much higher, or if the stock had been perceived to have } \\
\text { little potential for further increase (i.e., if equity had been overvalued), the firm } \\
\text { would have used equity instead. }\end{array}$ & 5 \\
\hline
\end{tabular}

Panel B. Validity of convertible bond theories

\begin{tabular}{|c|c|}
\hline \multicolumn{2}{|l|}{ Risk shifting rationale of Green $(1984)^{\mathrm{c}}$} \\
\hline Theory makes sense, but did not drive issuance decision. & $2(2 / 19)$ \\
\hline Rejected. & $17(17 / 19)$ \\
\hline \multicolumn{2}{|c|}{ Risk uncertainty rationale of Brennan and Kraus (1987) and Brennan and Schwartz (1988) } \\
\hline Supported. & $10(10 / 18)$ \\
\hline Rejected. & $7(7 / 18)$ \\
\hline Theory makes sense when times are bad, but did not drive issuance decision. & $1(1 / 18)$ \\
\hline \multicolumn{2}{|l|}{ Sequential financing rationale of Mayers $(1998)^{\mathrm{c}}$} \\
\hline Theory played a role in the issuance decision. & $1(1 / 18)$ \\
\hline Theory makes sense, but did not drive issuance decision. & $2(2 / 18)$ \\
\hline Rejected. & $15(15 / 18)$ \\
\hline \multicolumn{2}{|l|}{ Backdoor equity rationale of Stein $(1992)^{c}$} \\
\hline $\begin{array}{l}\text { Convertible debt is a kind of delayed equity: The stock at the moment of issuance } \\
\text { was perceived to be undervalued, and the firm would only want to issue equity at a } \\
\text { higher price. }\end{array}$ & $5(5 / 18)$ \\
\hline $\begin{array}{l}\text { Convertible debt is preferred to equity mainly because equity issuance sends a bad } \\
\text { signal about the firm to the market. }\end{array}$ & $0(0 / 21)$ \\
\hline $\begin{array}{l}\text { The expected negative stock reaction around the announcement of security } \\
\text { issuance is a major concern for the convertible issuance decision. }\end{array}$ & $0(0 / 21)$ \\
\hline $\begin{array}{l}\text { One reason, although not a major one, for not issuing equity was to avoid } \\
\text { sending a signal of firm overvaluation to the market. }\end{array}$ & $2(2 / 18)$ \\
\hline \multicolumn{2}{|l|}{ Is your convertible callable? If so, why did you include a call feature? } \\
\hline $\begin{array}{l}\text { Yes, useful to force conversion and get rid of debt overhang / Raise more debt / } \\
\text { Re-finance at lower cost. }\end{array}$ & $11(11 / 21)$ \\
\hline Yes, this was a standard feature and was necessary. & $2(2 / 21)$ \\
\hline Yes, useful to signal the potential to convert to a reasonably high price. & $1(1 / 21)$ \\
\hline No, firm does not want to pay for the call option. & $1(1 / 21)$ \\
\hline No, firm would not have funds to repay debt anyway. & $3(3 / 21)$ \\
\hline No, firm prepared to let convertibles run their course and convert. ${ }^{\mathrm{d}}$ & $2(2 / 21)$ \\
\hline
\end{tabular}


\begin{tabular}{|l|l|l|}
\hline No, the call provision would impair the marketability of the conversion instrument. & $1(1 / 21)$
\end{tabular}

Panel C. Role of investor demand and financial intermediaries

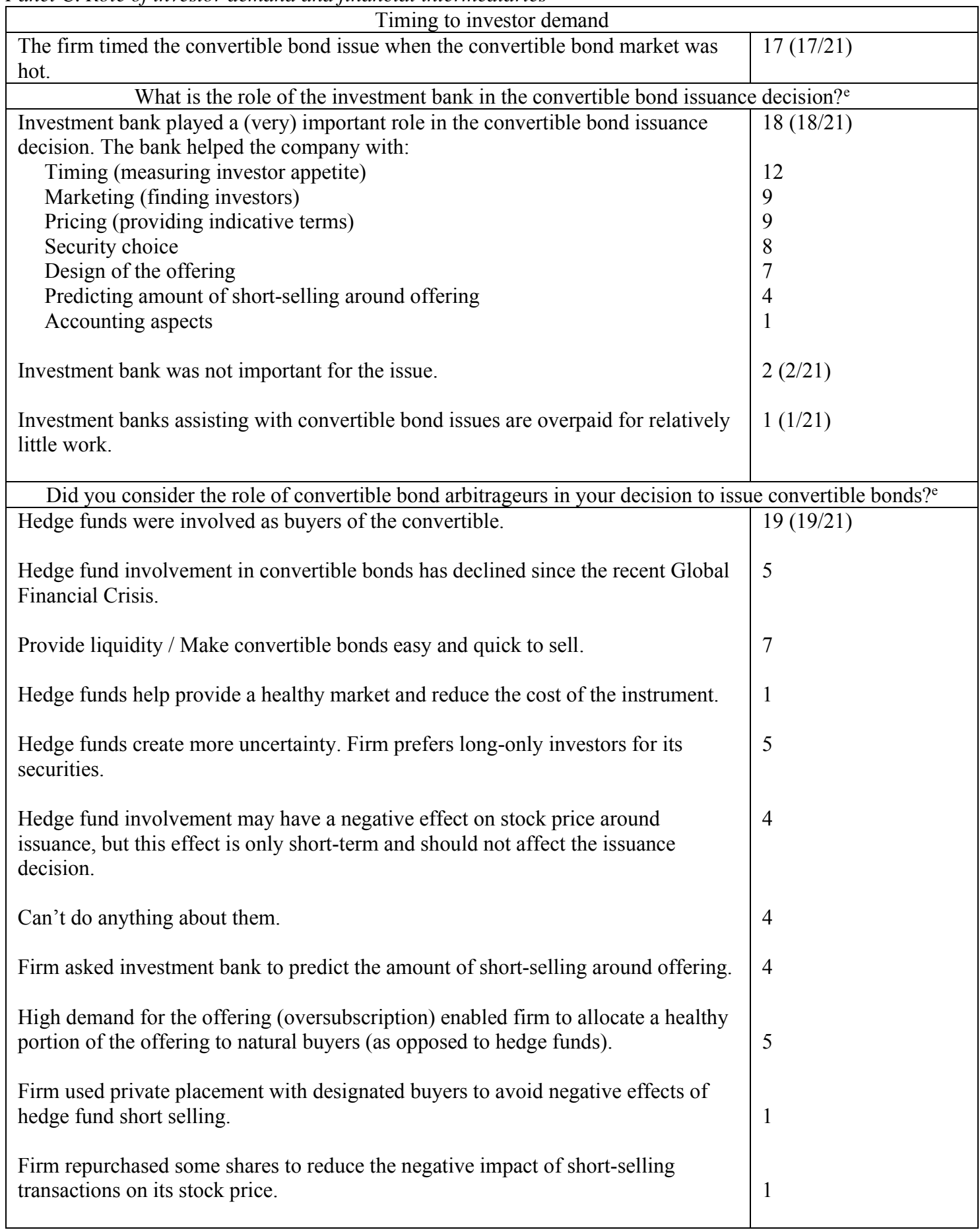

${ }^{\text {a }}$ When a fraction is indicated, the number of responses is measured as a proportion of total non-missing responses to a certain question. For firms with multiple convertible issues, we only use their most recent offering in tabulating the fraction. In cases where the respondents provide additional insights not covered by a specific interview question, the fraction is not indicated.

${ }^{\mathrm{b}}$ For one company that made two convertible bond issues over the research period, this argument only applied to one of the two issues.

${ }^{c}$ In the actual interviews, we briefly described each theory to the managers until we were sure that they understood the key assumptions and predictions of the theory. 
${ }^{d}$ The management of one of the companies that gave this answer was responsible for two convertible bond issues. This answer only applies to their most recent offering. The first issue was callable, because at that time the management found it useful to protect itself from paying a high coupon for too long.

${ }^{\mathrm{e}}$ The total number of observations for this question is larger than 21 , since a number of respondents provided more than one answer. 


\section{Table 5. Results of security choice analysis}

Description: This table reports results of a multinomial probit analysis of firms' choice between convertibles, straight bonds, and seasoned equity. The sample consists of 2,113 convertible debt offerings, 7,012 straight bond offerings, and 6,680 seasoned equity offerings made by U.S. firms, or 15,805 security offerings in total. The dependent variable is equal to one for convertibles, zero for straight bonds, and two for seasoned equity. We set convertibles as the baseline outcome. The output of the multinomial probit analysis therefore consists of two pairwise analyses: one analyzing the choice between convertibles and straight bonds, and one analyzing the choice between convertibles and seasoned equity. A positive (negative) coefficient sign reflects a higher (lower) probability of choosing convertibles over straight debt or equity. Independent variables are defined in Appendix B. Panel A reports full-sample results. Panel B compares results across subsamples of security issuers with relatively good and bad credit ratings. Credit rating is measured as the S\&P domestic long-term issuer credit rating (Compustat data item SPLTICRM) as of the issue month. Investment grade issuers are issuers with a credit rating of $\mathrm{BBB}$ or better, while non-investment grade ratings are issuers rated below BBB as well as non-rated issuers. Panel C compares results across subsamples of debt-like and equity-like convertible bonds. We define debt-like convertibles as convertibles with a conversion premium higher than the sample median of $25 \%$, and equity-like convertibles as convertibles with a conversion premium lower than or equal to the sample median of $25 \%$. We obtain the conversion premium from SDC. Straight bond and seasoned equity samples are the same as those used in the baseline analyses in Panel A. $t$-statistics (in parentheses) are based on robust standard errors clustered per year. $N$ denotes the total number of observations. The Wald $\chi^{2}$ statistic is for the explanatory power of the full multinomial probit model consisting of the two pairwise analyses. ${ }^{*},{ }^{* *}$, and ${ }^{* * *}$ indicate significance at less than $10 \%, 5 \%$, and $1 \%$, respectively.

Interpretation: In the baseline regressions in Panel A, residual yield spread positively affects the likelihood of choosing convertibles instead of straight debt, and book-to-market positively affects the likelihood of choosing convertibles instead of equity. These findings confirm the interview results that firms choose between convertibles and bonds based on feature-adjusted (residual) yield differentials, and between convertibles and equity based on equity misvaluation. Panel B shows that residual yield spreads only have a significant impact on the convertible versus straight bond choice for convertible issuers with non-investment grade credit ratings. This finding is consistent with the fact that firms with higher debt constraints (as captured by a worse credit rating) have higher benefits in choosing the least costly debt security. Panel $\mathrm{C}$ shows that yield spreads only have a significant impact on the convertible versus straight bond choice for debt-like convertibles (with a relatively high conversion premium), while cost of equity (measured by book-to-market) only has a significant impact on the convertible versus equity choice for equity-like convertibles (with a relatively lower conversion premium.) This result supports the view that when firms perceive their equity as undervalued by the market (reflected by a higher conversion premium), they mainly consider cost differentials between convertibles and straight bonds while having ruled out equity in a previous step of their decision process. This is where most of our interview firms fit in. Conversely, when firms perceive their stock as more favorably valued by the market (leading to a lower conversion premium), they consider equity a viable option and decide between convertibles and equity based on the cost of equity. 
Panel A: Full sample

\begin{tabular}{lcc}
\hline Variables & Convertibles versus bonds & Convertibles versus equity \\
& $(1)$ & $(2)$ \\
\hline Residual yield spread & $5.941^{* *}$ & $(.571$ \\
& $(2.06)$ & $(0.67)$ \\
Book-to-market & -0.145 & $0.159^{* * *}$ \\
& $(-1.63)$ & $(2.87)$ \\
Volatility & $0.127^{* * *}$ & $-0.064^{* * *}$ \\
Return on assets & $(3.81)$ & $(-2.77)$ \\
& $-0.889^{* *}$ & $0.697^{* * *}$ \\
Leverage & $(-2.49)$ & $(4.38)$ \\
& $-1.060^{* * *}$ & $0.246^{*}$ \\
Cash & $(-5.91)$ & $(1.96)$ \\
& $1.794^{* * *}$ & $0.485^{* * *}$ \\
Firm age & $(7.42)$ & $(3.05)$ \\
& $-0.010^{* * *}$ & $0.005^{* * *}$ \\
Firm size & $(-6.86)$ & $(3.11)$ \\
& $-0.361^{* * *}$ & $0.305^{* * *}$ \\
Treasury Bill rate & $(-11.24)$ & $(8.66)$ \\
& -0.041 & 0.007 \\
Market runup & $(-1.10)$ & $(0.14)$ \\
& 0.072 & -0.112 \\
Default spread & $(0.10)$ & $(-0.18)$ \\
Consumer confidence & 0.162 & 0.008 \\
Intercept & $(0.84)$ & $(0.04)$ \\
& 0.066 & $-1.406^{*}$ \\
Wald $\chi^{2}$ & $(0.09)$ & $(-1.82)$ \\
$\mathrm{N}$ & $1.872^{* * *}$ & $-2.417^{* * *}$ \\
\end{tabular}


Panel B: Non-investment grade versus investment grade issuers

\begin{tabular}{|c|c|c|c|c|}
\hline \multirow[t]{2}{*}{ Variables } & \multicolumn{2}{|c|}{ Non-investment grade } & \multicolumn{2}{|c|}{ Investment grade } \\
\hline & $\begin{array}{c}\text { Convertibles versus bonds } \\
\text { (1a) }\end{array}$ & $\begin{array}{c}\text { Convertibles versus equity } \\
(2 \mathrm{a})\end{array}$ & $\begin{array}{c}\text { Convertibles versus bonds } \\
\text { (1b) }\end{array}$ & $\begin{array}{c}\text { Convertibles versus equity } \\
(2 \mathrm{~b})\end{array}$ \\
\hline \multirow[t]{2}{*}{ Residual yield spread } & $6.022^{* *}$ & 1.681 & 3.364 & 1.720 \\
\hline & $(2.03)$ & $(0.70)$ & $(0.93)$ & $(0.49)$ \\
\hline \multirow[t]{2}{*}{ Book-to-market } & $-0.326^{* * *}$ & $0.142^{* *}$ & -0.463 & 0.189 \\
\hline & $(-3.59)$ & $(2.35)$ & $(-1.56)$ & $(1.12)$ \\
\hline \multirow[t]{2}{*}{ Volatility } & $0.068^{* *}$ & $-0.067^{* * *}$ & $0.324^{* * *}$ & $-0.092^{*}$ \\
\hline & $(2.20)$ & $(-2.72)$ & $(5.03)$ & $(-1.90)$ \\
\hline \multirow[t]{2}{*}{ Return on assets } & -0.184 & $0.645^{* * *}$ & $-5.937^{* * *}$ & 0.492 \\
\hline & $(-0.68)$ & $(4.02)$ & $(-7.68)$ & $(0.56)$ \\
\hline \multirow[t]{2}{*}{ Leverage } & $-1.512^{* * *}$ & $-0.278^{* *}$ & $-0.824^{* *}$ & $-1.497^{* * *}$ \\
\hline & $(-7.67)$ & $(-2.02)$ & $(-2.05)$ & $(-3.30)$ \\
\hline \multirow[t]{2}{*}{ Cash } & $1.867^{* * *}$ & $0.477^{* * *}$ & $2.604^{* * *}$ & -3.054 \\
\hline & $(6.48)$ & $(2.93)$ & $(4.27)$ & $(-3.24)$ \\
\hline \multirow[t]{2}{*}{ Firm age } & $-0.006^{* * *}$ & -0.003 & $-0.005^{* *}$ & $-0.004^{*}$ \\
\hline & $(-3.41)$ & $(-1.07)$ & $(-2.08)$ & $(-1.70)$ \\
\hline \multirow[t]{2}{*}{ Firm size } & $-0.238^{* * *}$ & $0.330^{* * *}$ & $-0.503^{* * *}$ & -0.059 \\
\hline & $(-5.88)$ & $(8.16)$ & $(-11.57)$ & $(-0.93)$ \\
\hline \multirow[t]{2}{*}{ Treasury Bill rate } & -0.011 & -0.006 & -0.152 & 0.062 \\
\hline & $(-0.29)$ & $(0.12)$ & $(-0.95)$ & $(0.40)$ \\
\hline \multirow[t]{2}{*}{ Market runup } & 0.117 & 0.112 & 0.585 & -0.327 \\
\hline & $(0.15)$ & $(0.17)$ & $(0.60)$ & $(-0.35)$ \\
\hline \multirow[t]{2}{*}{ Default spread } & -0.204 & -0.009 & 0.124 & -0.122 \\
\hline & $(-0.94)$ & $(-0.05)$ & $(0.49)$ & $(-0.31)$ \\
\hline \multirow{2}{*}{ Consumer confidence } & -0.557 & $-1.467^{*}$ & 0.510 & -0.680 \\
\hline & $(-0.62)$ & $(-1.78)$ & $(0.63)$ & $(-0.73)$ \\
\hline \multirow[t]{2}{*}{ Intercept } & $1.560^{* * *}$ & $-2.554^{* * *}$ & $2.834^{* * *}$ & 0.697 \\
\hline & $(5.58)$ & $(-8.86)$ & $(6.63)$ & $(1.54)$ \\
\hline Wald $\chi^{2}$ & $5,189.85^{* * *}$ & & $2,617.91^{* * *}$ & \\
\hline $\mathrm{N}$ & 11,074 & & 4,731 & \\
\hline
\end{tabular}


Panel C: High versus low conversion premium

\begin{tabular}{|c|c|c|c|c|}
\hline \multirow[t]{2}{*}{ Variables } & \multicolumn{2}{|c|}{ Debt-like } & \multicolumn{2}{|c|}{ Equity-like } \\
\hline & $\begin{array}{c}\text { Convertibles versus bonds } \\
\text { (1a) }\end{array}$ & $\begin{array}{l}\text { Convertibles versus equity } \\
(2 \mathrm{a})\end{array}$ & $\begin{array}{c}\text { Convertibles versus bonds } \\
\text { (1b) }\end{array}$ & $\begin{array}{c}\text { Convertibles versus equity } \\
(2 \mathrm{~b})\end{array}$ \\
\hline \multirow[t]{2}{*}{ Residual yield spread } & $10.791^{* *}$ & 6.264 & 4.692 & 0.502 \\
\hline & $(2.24)$ & $(1.42)$ & $(1.25)$ & $(0.15)$ \\
\hline \multirow[t]{2}{*}{ Book-to-market } & $-0.235^{* * *}$ & 0.082 & -0.003 & $0.292^{* * *}$ \\
\hline & $(-2.97)$ & $(1.02)$ & $(-0.03)$ & $(4.87)$ \\
\hline \multirow[t]{2}{*}{ Volatility } & $0.132^{* * *}$ & $-0.058^{*}$ & $0.084^{*}$ & $-0.098^{* * *}$ \\
\hline & $(4.63)$ & $(-1.83)$ & $(1.74)$ & $(-4.12)$ \\
\hline \multirow[t]{2}{*}{ Return on assets } & $-0.906^{* *}$ & $0.688^{* * *}$ & $-0.802^{* *}$ & $0.631^{* * *}$ \\
\hline & $(-2.18)$ & $(3.35)$ & $(-2.43)$ & $(3.44)$ \\
\hline \multirow[t]{2}{*}{ Leverage } & $-1.182^{* * *}$ & $-0.351^{* * *}$ & $-0.786^{* * *}$ & 0.026 \\
\hline & $(-6.99)$ & $(-2.66)$ & $(-4.50)$ & $(0.19)$ \\
\hline \multirow{2}{*}{ Cash } & $2.164^{* * *}$ & $1.003^{* * *}$ & $1.309^{* * *}$ & 0.164 \\
\hline & $(9.40)$ & $(6.05)$ & $(5.29)$ & $(0.93)$ \\
\hline \multirow[t]{2}{*}{ Age } & $-0.014^{* * *}$ & $-0.009^{* * *}$ & $-0.003^{*}$ & 0.001 \\
\hline & $(-8.48)$ & $(-4.42)$ & $(-1.90)$ & $(1.17)$ \\
\hline \multirow[t]{2}{*}{ Firm size } & $-0.213^{* * *}$ & $0.461^{* * *}$ & $-0.453^{* * *}$ & $0.205^{* * *}$ \\
\hline & $(-7.03)$ & $(13.18)$ & $(-11.71)$ & $(5.75)$ \\
\hline \multirow[t]{2}{*}{ Treasury Bill rate } & -0.024 & 0.003 & -0.020 & 0.005 \\
\hline & $(-0.50)$ & $(0.04)$ & $(-0.37)$ & $(0.10)$ \\
\hline \multirow[t]{2}{*}{ Market runup } & -0.154 & -0.124 & 0.412 & 0.384 \\
\hline & $(-0.23)$ & $(-0.20)$ & $(0.41)$ & $(0.49)$ \\
\hline \multirow[t]{2}{*}{ Default spread } & -0.277 & -0.128 & 0.004 & 0.118 \\
\hline & $(-1.27)$ & $(-0.63)$ & $(0.02)$ & $(0.71)$ \\
\hline \multirow[t]{2}{*}{ Consumer confidence } & 0.438 & -1.062 & 0.324 & -1.141 \\
\hline & $(0.51)$ & $(-1.19)$ & $(0.37)$ & $(-1.50)$ \\
\hline \multirow[t]{2}{*}{ Intercept } & 0.379 & $-4.023^{* * *}$ & $1.871^{* * *}$ & $-2.372^{* * *}$ \\
\hline & $(1.28)$ & $(-13.13)$ & $(5.18)$ & $(-8.32)$ \\
\hline Wald $\chi^{2}$ & $3,218.90^{* * *}$ & & $5,532.00^{* * *}$ & \\
\hline $\mathrm{N}$ & 14,543 & & 14,694 & \\
\hline
\end{tabular}




\section{Appendix A. Interview design and execution}

We adopted a semi-structured interview approach with a core set of structured questions in each interview to facilitate comparisons across convertible bond issuers. ${ }^{a}$ However, we still allowed flexibility for specific topics to be discussed in greater depth in different interviews, depending on what interesting avenues emerged.

We compiled a list of interview questions based on general capital structure theories and convertible bond issuance motives suggested by the literature, as well as on recent changes in the convertible bond market. We revised the list several times to enhance the clarity and relevance of the questions and set its length so as to be able to complete each interview within one hour. According to Gillham (2008), interviews lasting longer than one hour are too demanding and, therefore, lead to data quality loss. The actual interviews varied in length between slightly less than half an hour and slightly more than one hour.

We opened each interview asking the executive to describe, in his own words, why his company chose convertible bonds instead of straight bonds or equity. The purpose of this initial question was to avoid influencing the viewpoints of the executives with leading questions. We believe that the possibility to ask such open-ended questions is a key advantage of interviews compared with surveys. After the first question we asked the executives a number of more specific questions to obtain a deeper understanding of their motives. As suggested by Bradburn et al. (2004), we asked more sensitive questions (e.g., about the company's viewpoints about hedge fund involvement in their offering) later in the interview. The first column of Table 4 provides an overview of the interview questions.

All interviews were conducted by authors of this study. Field interviews took place at the company headquarters. Interview tapes were transcribed by two professional transcribers following the guidelines outlined in Kvale and Brinkmann (2009). Subsequently, the interview transcripts were thoroughly checked by the interviewer for any remaining errors or omissions.

\footnotetext{
${ }^{a}$ While we attempted to ask all core questions in all interviews, there were some omissions, mainly due to time constraints. Table 4 indicates the number of respondents for each question.
} 
Appendix B. Measurement of variables included in the security choice analysis

Description: This table outlines how we measured the independent variables included in the security choice analysis reported in Table 5. It also provides the sources from which we obtained the variables. Variables are presented in the order in which they are included in Table 5.

\begin{tabular}{|c|c|}
\hline Variable & Definition and source(s) \\
\hline Residual yield spread & 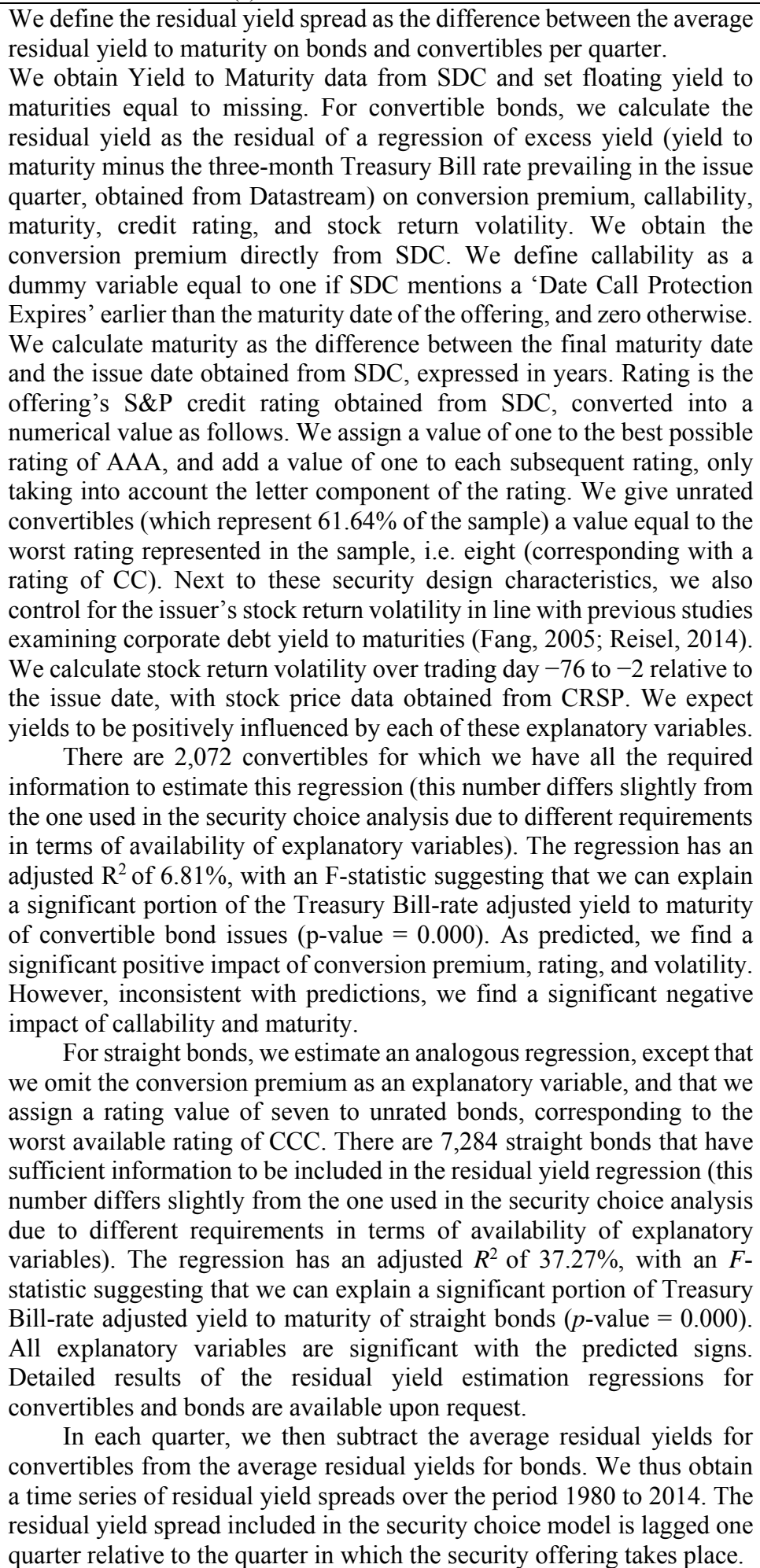 \\
\hline
\end{tabular}




\begin{tabular}{|c|c|}
\hline Book-to-market & $\begin{array}{l}\text { Ratio of book value to market value of equity. Book value is obtained } \\
\text { from Compustat (item CEQ) and measured at the fiscal year end prior to } \\
\text { the issue date. Market equity value is obtained from CRSP and measured } \\
\text { as of the month preceding the issue month. }\end{array}$ \\
\hline Volatility & $\begin{array}{l}\text { Standard deviation of stock returns for the } 60 \text { trading days before the } \\
\text { issue month. }\end{array}$ \\
\hline Volatility change & $\begin{array}{l}\text { Standard deviation of stock returns for the } 60 \text { trading days prior to the } \\
\text { issue month minus standard deviation of stock returns for the } 60 \text { trading } \\
\text { days after the issue month. }\end{array}$ \\
\hline Return on assets & $\begin{array}{l}\text { Ratio of operating income before depreciation (item OIBDP) to total } \\
\text { assets (item AT). Both variables are obtained from Compustat and } \\
\text { measured at the fiscal year end prior to the issue date. }\end{array}$ \\
\hline Leverage & $\begin{array}{l}\text { Ratio of sum of short-term debt (item DLC) and long-term debt (item } \\
\text { DLTT) to total assets. Both variables are obtained from Compustat and } \\
\text { measured at the fiscal year end prior to the issue date. }\end{array}$ \\
\hline Cash & $\begin{array}{l}\text { Ratio of cash and marketable securities (item CHE) to total assets. Both } \\
\text { variables are obtained from Compustat and measured at the fiscal year } \\
\text { end prior to the issue date. }\end{array}$ \\
\hline Firm age & $\begin{array}{l}\text { Age, in years, measured from the first date the company is covered in } \\
\text { CRSP until the issue date. }\end{array}$ \\
\hline Firm size & $\begin{array}{l}\text { Logarithm of the book value of total assets, obtained from Compustat and } \\
\text { measured at the fiscal year end prior to the issue date. }\end{array}$ \\
\hline Treasury Bill rate & $\begin{array}{l}\text { Change in the three-month U.S. Treasury Bill rate over the quarter } \\
\text { preceding the quarter in which the security offering takes place. We } \\
\text { obtain U.S. Treasury Bill rates from Datastream. }\end{array}$ \\
\hline Market runup & $\begin{array}{l}\text { Quarterly return (measured as a logarithmic growth rate) over the S\&P } \\
500 \text { composite price index, over the quarter preceding the quarter in } \\
\text { which the security offering takes place. We obtain the S\&P } 500 \text { price } \\
\text { index from Datastream. }\end{array}$ \\
\hline Default spread & $\begin{array}{l}\text { Change in the spread between average yields on Moody's Aaa and Baa } \\
\text { rated long-term corporate bonds over the quarter preceding the quarter in } \\
\text { which the security offering takes place. We obtain yields on Aaa and Baa } \\
\text { rated corporate bonds from Datastream. }\end{array}$ \\
\hline Consumer confidence & $\begin{array}{l}\text { Logarithmic growth rate of the University of Michigan Consumer } \\
\text { Sentiment Index over the quarter preceding the quarter in which the } \\
\text { security offering takes place. We obtain this consumer sentiment index } \\
\text { from Datastream. }\end{array}$ \\
\hline
\end{tabular}

